\title{
Franz Joseph Haydn's writing for wind instruments and the evolution of the military band and orchestral wind section
}

\author{
Jonathan Neiderhiser \\ West Virginia University
}

Follow this and additional works at: https://researchrepository.wvu.edu/etd

\section{Recommended Citation}

Neiderhiser, Jonathan, "Franz Joseph Haydn's writing for wind instruments and the evolution of the military band and orchestral wind section" (2008). Graduate Theses, Dissertations, and Problem Reports. 2845.

https://researchrepository.wvu.edu/etd/2845

This Dissertation is protected by copyright and/or related rights. It has been brought to you by the The Research Repository @ WVU with permission from the rights-holder(s). You are free to use this Dissertation in any way that is permitted by the copyright and related rights legislation that applies to your use. For other uses you must obtain permission from the rights-holder(s) directly, unless additional rights are indicated by a Creative Commons license in the record and/ or on the work itself. This Dissertation has been accepted for inclusion in WVU Graduate Theses, Dissertations, and Problem Reports collection by an authorized administrator of The Research Repository @ WVU.

For more information, please contact researchrepository@mail.wvu.edu. 
Franz Joseph Haydn's Writing for Wind Instruments and the Evolution of the Military Band and Orchestral Wind Section

\author{
Jonathan Neiderhiser
}

\author{
Research Project submitted to the \\ College of Creative Arts \\ at West Virginia University \\ in partial fulfillment of the requirements \\ for the degree of \\ Doctor of Musical Arts \\ in Performance: Conducting
}

Dr. Kathleen Shannon, chair

Prof. John Hendricks

Dr. Mary Ferer

Dr. Virginia Thompson

Dr. Jay Malarcher

Division of Music

Morgantown, West Virginia

2008

Keywords: Franz Joseph Haydn, military music, wind band, orchestral winds 


\begin{abstract}
Franz Joseph Haydn's Writing for Wind Instruments and the Evolution of the Military Band and Orchestral Wind Section

Jonathan Neiderhiser
\end{abstract}

The compositional career of Franz Joseph Haydn (1732-1809) spans a crucial period in Western musical history. Haydn's early compositions show the influence of the late Baroque, while his late symphonies and Masses can be heard as early examples of musical Romanticism. At this same time, the development of new wind instruments within European military bands heavily influenced the establishment of the symphony orchestra, as instruments initially deemed inappropriate for indoor performance became accepted as core members of the ensemble. Haydn's critical role in the growth of the symphony has long been acknowledged, but the increasing sophistication of his wind writing over the course of his work, and the importance of this development to his overall symphonic style, is often overlooked. Viewed in its historical context, Haydn's career can be seen as a microcosm of the evolution of symphonic music over the course of the late 1700 s and early 1800 s, particularly in regard to the role of wind instruments in that evolution. 


\section{Acknowledgements}

I would like to express my thanks to all of the members of my committee for all of their help and encouragement throughout this process. In particular, I would like to thank my director, Dr. Kathleen Shannon, for her assistance and understanding. Special thanks as well to Dr. Mary Ferer, whose graduate seminar on Haydn and Mozart introduced me to Haydn's wind works and the context of late $18^{\text {th }}$-century Viennese musical culture.

Thanks as well to Professor Don Wilcox, Professor John Hendricks, Dr. Christopher Wilkinson, Dr. Andrew Kohn, and all of my truly inspirational teachers at WVU.

Many thanks to the staff and administration of the Division of Music, particularly Dr. Keith Jackson, for helping me get through the doctoral process, particularly in allowing me to give my "final" recital early so that I could make the trip to South Dakota with only this paper left to do.

Thank you to all of the library staff and personnel for all of their help.

A sincere thanks to all of my new colleagues at the University of Sioux Falls for having patience with me as I've taken on two big tasks at once - starting a full-time faculty position and writing a doctoral research paper.

And, most of all, a huge thank you to my family, on both sides of the country, and especially to my "first reader" and beloved wife, Dr. Jenny Bangsund. 


\section{Table of Contents}

Introduction and Review of Literature 1

I. The Development of the Hautbois Band: Haydn's Early Wind Divertimenti 9

II. Harmoniemusik in the European Court: Haydn’s Esterháza Symphonies 19

III. The Wind Band Becomes a Concert Ensemble: Haydn's Works for Winds 29

IV. Military Music and the Sublime: Haydn's “London” Symphonies 45

V. The Decline of the Courtly Wind Ensemble: Haydn's Late Masses 63

$\begin{array}{ll}\text { Conclusion } & 72\end{array}$

$\begin{array}{ll}\text { Bibliography } & 77\end{array}$ 
Introduction and Review of Literature

Though he was widely acclaimed as the world's greatest composer during his lifetime, Franz Joseph Haydn (1732-1809) has been viewed by subsequent generations of musical cognoscenti with less enthusiasm. Though many scholars continue to refer to Haydn as "the father of the symphony" and the perfector of the string quartet, the truly innovative nature of his music is often overlooked. Haydn's standing as a musical genius has been eclipsed in latter generations by the reputations of his contemporary Mozart - who, in the wake of the popular stage and screen depictions of Amadeus, has come to be viewed as the prototypical young genius who died too young, a sort of eighteenth-century James Dean - and Haydn's student Beethoven, the tortured Romantic genius par excellence. Popular consensus has deemed Haydn's works overly formal and reserved in comparison to the operas of Mozart and the symphonies of Beethoven; this oversimplified view entirely ignores contemporary accounts of Haydn's music and the emotions it stirred in the listeners of his time.

Perhaps the most impassioned descriptions of Haydn's music are the newspaper accounts surrounding the composer's one hundredth symphony, the so-called "Military" Symphony.

London's Morning Chronicle, for instance, relates the following:

Another new Symphony, by Haydn, was performed for the second time; and the middle movement was again received with absolute shouts of applause. Encore! encore! encore! resounded from every seat: the Ladies themselves could not forbear. It is the advancing to battle; and the march of men, the sounding of the charge, the thundering of the onset, the clash of arms, the groans of the wounded, and what may well be called the hellish roar of war increase to a climax of horrid sublimity! which, if others can conceive, he alone can execute; at least he alone hitherto has affected these wonders. ${ }^{1}$

These words can hardly be read as describing a cool Classicism, and the assertion that such emotional mastery was unique to the music of Haydn, who "alone" could present such a stirring

\footnotetext{
${ }^{1}$ H.C. Robbins Landon, Haydn: Chronicle and Works, Vol. III: Haydn in England 1791-1795. (Bloomington, IN: Indiana University Press, 1976), 247; punctuation original.
} 
musical scene, belies the amiably pleasant image of genial "Papa Haydn" that has been passed down in music appreciation textbooks.

The premiere of the "Military" Symphony can be viewed as one of the highest points of Haydn's life; Haydn scholar H.C. Robbins Landon goes so far as to proclaim the "Military" Symphony "the greatest success of [Haydn's] whole career," noting that in this particular piece the composer "had somehow caught the spirit of the day in a miraculous way.", Many of the elements underlying this enormous success can be pinpointed easily. The "Military" Symphony premiered in London when Haydn's popularity was at its peak; each new symphony produced in England generated enormous public interest fed by almost unprecedented media coverage. The public orchestras of London were larger and more accomplished than those that had been at the composer's disposal within the Esterházy court, giving Haydn the license to expand his orchestral palette both in terms of instrumental color and virtuosic possibility. Visiting a foreign country gave Haydn - by all accounts a keen observer of culture - the chance to explore new modes of expression shaped by the events and trends he witnessed and meticulously recorded in his travel journals. Finally, and perhaps most importantly, the "Military" Symphony appealed directly to popular taste by taking advantage of the patriotism sweeping across Britain at the dawn of the Napoleonic wars. Haydn's symphony drew upon the prevailing trend towards military themes in the British arts of the late eighteenth century, garnering instant success by consciously tapping into the "spirit of the day" with a work whose compositional excellence far surpassed much of the era's standard fare.

In creating the vivid battle scenario that would so thrill his audience, Haydn turned to a musical genre that is often overlooked by present-day scholars of the Classical period: the repertoire of the eighteenth-century military band. The Allegretto second movement of the

\footnotetext{
${ }^{2}$ Landon, Haydn Chronicle III, 246.
} 
symphony, in particular, contains a number of musical elements drawn directly from military wind music, including the introduction of percussion instruments previously relegated to battlefield duty. His evocation of the military band was so successful that Haydn was able to transcribe the Allegretto for wind band while making very few alterations to the symphonic score. The phenomenal success of the Allegretto in both instrumentations demonstrates Haydn's compositional mastery and his ability to blend popular stylistic elements and formal symphonic structure. The movement's overwhelming acclaim also stands as a testimony to the significance of military wind music to the cultural imagination of late eighteenth-century Europe.

Haydn's compositional career can be viewed as a life-long process of musical development. Haydn's early compositions show the influence of the late Baroque, particularly his symphonic trilogy Le Matin, Le Midi, and La Soir, which clearly draw upon the model of Vivaldi's Four Seasons. His late symphonies and Masses, on the other hand, can be heard as early examples of musical Romanticism, incorporating dramatic elements that foreshadow the stormy works of Beethoven. Haydn's compositional development similarly spans a period of great change in the status of music throughout Europe. His initial forays into composition came under the system of patronage carried over from earlier periods in music history, while his final works were premiered and distributed by public artistic organizations in a free market economy. When Haydn began composing, the symphony was still a relative curiosity, an expansion of the opera overture. By the time he had finished, the symphony was held to be the genre of choice for serious artistic expression. Viewed in its historical context, Haydn's career can be seen as a microcosm of the evolution of symphonic music over the course of the late 1700s and early 1800s. 
Attendant to the rise of the symphony orchestra was a similarly revolutionary growth of the wind band within the European military. The development of the wind ensemble was, in fact, one of the key factors in the evolution of the symphony orchestra, as various wind instruments initially thought unsuitable for indoor playing began to be incorporated within the string-based sound of the operatic pit orchestra. The oboe, bassoon, and horn were early additions to the pre-Classical orchestra borrowed directly from the military band. In the mid1700s the clarinet began to find favor on both the battlefield and the concert stage, joining reinstituted Baroque-era brass instruments such as the trumpet and trombone. Eventually, military percussion instruments - the triangle, bass drum, and cymbals - would find their way into the orchestra, solidifying what has become the standard symphonic ensemble.

Just as Haydn's career can be examined in the context of the evolution of the symphony orchestra, so too can the composer's writing for wind instruments be viewed as an emblem of the maturation of the wind ensemble both in the context of the military band and in that of the symphonic wind section. Among the pre-symphonic works of Haydn's early days as a court composer are a collection of divertimenti and partitas written exclusively for winds, generally in the sextet form of the hautbois ensemble, the standard instrumentation of the military at the time. Haydn's appointment as composer to the Esterházy court coincided with the establishment of a courtly wind band; because the Esterházy band served as the wind section of the court's opera orchestra, this hautbois ensemble directly influenced Haydn's compositional style. As the status of the military band grew, Haydn composed works for specific wind ensembles on several occasions, including marches for the Esterházy court band, for wind ensembles of neighboring courts, and for royal and civic military bands in England. During his famed London journeys, a deep public interest in military affairs in Britain, combined with access to symphonic wind 
sections larger than Haydn had ever worked with before, allowed the composer to create a set of twelve symphonies that would forever cement his reputation as a master composer. Upon returning from England, the elderly Haydn purposefully continued to develop his skills in wind composition, incorporating movements for wind ensemble alone within larger orchestral compositions. His late Masses demonstrate his mastery of wind writing within the symphonic tonal palette.

Haydn's prominent role in the development of the sonata allegro form, the symphony, and the string quartet has inspired a great deal of scholarly work over the past two centuries. Yet the evolution of Haydn's writing for wind instruments and its ties to the historical development of the military wind band and the integration of military wind instruments within the standard symphony orchestra have remained largely unexplored. While numerous volumes have covered the symphonies, the string quartets, the Masses, the oratorios, and other works in great detail, only one scholarly source seems to have been written dealing exclusively with music for by Haydn wind band: an article by English musicologist Karl Haas, entitled "Haydn’s English Military Marches," published in The Score journal in 1950. Roger Hellyer's survey of “The Wind Ensemble of the Esterházy Princes, 1761-1813” in Haydn Yearbook, volume 5, examines the Esterházy court records for basic information about the maintenance and upkeep of the court's various wind ensembles, but provides no specific discussion of Haydn's music for the ensemble. With so little material dedicated explicitly to the topic, an examination of Haydn's writing for wind instruments must draw from literature in a number of related fields.

Volumes of general information on Haydn's life and work are numerous and easy to find, though no more thorough study can be made than H. C. Robbins Landon's comprehensive fivevolume Haydn: Chronicle and Works. This remarkable resource provides a year-by-year 
chronicle of Haydn's activities, background information on each composition in chronological sequence, and a host of primary source material including letters, concert advertisements, contracts, and diary entries. The meticulous detail of Landon's study makes other Haydn biographies more or less redundant, though contemporary accounts by Albert Christoph Dies ("Biographical Accounts of Joseph Haydn, According to His Spoken Narration") and Georg August Greisinger ("Biographical Notes Concerning Joseph Haydn”) provide valuable eyewitness testimony.

Because the later symphonies, in particular the "Military" Symphony, mark a crucial point in the development of Haydn's mastery of wind writing, much important information can be gleaned from a wide range of scholarly discussions of the London-era symphonies and their historical context. Once again, H. C. Robbins Landon's study of The Symphonies of Joseph Haydn is the most meticulous, with in-depth discussion of each of the 104 symphonies; the volume also briefly examines the wind divertimenti in a chapter on the pre-symphonic music. Christopher Hogwood's volume on Haydn's Visits to London contains much important information, as does David P. Schroeder's text Haydn and the Enlightenment: the Late Symphonies and Their Audience. Betty Matthews provides an even more focused study of Haydn's activities in London in an article detailing "Haydn's Visit to Hampshire and the Isle of Wight, Described from Contemporary Sources." The London period is easily the most studied of Haydn's entire career, and these resources furnish a rich backdrop in which the London-era marches, in particular, can be better examined.

Outside of the field of Haydn research, several important studies on the history and development of the wind ensemble provide crucial information for this study. Frederick Fennell's Time and the Winds, Richard Franko Goldman's The Concert Band, and David 
Whitwell's multi-volume History and Literature of the Wind Band and Wind Ensemble represent the finest scholarship on the history of the concert wind ensemble and its music. A particularly helpful resource for various aspects of military wind band scholarship can be found in the work of British historian Henry George Farmer, author of several important texts on military music, including Military Music, The Rise and Development of Military Music, and the collection Handel's Kettledrums, and Other Papers on Military Music. Because the evolution of the wind band was historically tied to the refinement of the standard symphony orchestra, John Spitzer and Neal Zaslaw's The Birth of the Orchestra: History of an Institution, 1650-1815 is indispensable. The years represented in the title can also be used to frame the historical period in which the hautbois ensemble and the Harmonie band flourished, creating an interesting parallel between the formation of the symphony orchestra and the development of the wind ensemble with which Haydn would have been familiar.

An additional category of scholarship that helps to inform a study of Haydn's wind music is a series of studies of concert life and artistic trends prevalent during the composer's lifetime. Mary Sue Morrow provides an important outlook on the contemporary European cultural scene in her volume on Concert Life in Haydn's Vienna, while Simon McVeigh examines the concurrent British outlook in his Concert Life in London from Mozart to Haydn. Both texts give invaluable background information on the various musical ensembles of the time and their cultural milieu. An additional source with particular interest in the study of the London-period works is Paul Langford's Englishness Identified: Manners and Character 1650-1800, an examination of character traits commonly attributed to British culture at the time. Another particularly useful cultural study is Thomas Tolley's Painting the Cannon's Roar: Music, the 
Visual Arts and the Rise of an Attentive Public in the Age of Haydn, which explores Haydn's output in the context of contemporary trends in the visual arts throughout Europe.

In terms of the music itself, the "Military" Symphony is easily available in numerous publications, though Haydn's music for winds alone - including the Harmonie arrangement of the "Military" Symphony - has not been widely reproduced. The Joseph Haydn-Institut in Köln has produced an opera omnia edition of Haydn's music that includes almost all of the music for winds. The opera Armide and the expanded version of the Seven Last Words each comprise a single volume in the set, while the various marches are included in a volume of Tänze und Märsche. The wind version of the "Military" Symphony's second movement is contained as an appendix to the symphony within the collection. The only notable absence is the incidental music to the play Alfred, which does not appear to have been covered yet by the Haydn-Institut.

When the overall historical and cultural context of Haydn's wind music is considered, these works can be shown to mirror the growth of wind music both within and outside of the symphony orchestra in the Classical and early Romantic periods. Haydn's critical role in the growth of the symphony has long been acknowledged, but the increasing sophistication of his wind writing over the course of his work, and the importance of this development to his overall symphonic style, is often overlooked. Viewed in its historical context, Haydn's career can be seen as a microcosm of the evolution of symphonic music over the course of the late 1700s and early 1800 s, particularly in regard to the role of wind instruments in that evolution. 


\section{The Development of the Hautbois Band: \\ Haydn's Early Wind Divertimenti}

Evidence of wind instrumental music can be traced to the earliest human societies, where ancient visual depictions show primitive pipe and reed instruments being played in a variety of sacred and secular ceremonies. Because most early religions viewed the human breath as an extension of the spirit, wind instruments carried special connotations in religious services and civic ceremonies. The ideological link between wind music and spirituality carried over into the establishment of Christianity, giving wind instruments a place of prominence in Western music throughout the Middle Ages and into the Renaissance and early Baroque periods. Though written parts for specified instruments would not come into common practice until the time of Andrea and Giovanni Gabrieli, wind instruments were often used in medieval and Renaissance music to embellish sacred vocal works. In the public sphere, brass instrumentalists were hired by civic governments to punctuate important events and to assist in communal time-keeping by playing "tower music" at key points over the course of the day.

Not long before Haydn's birth, however, public wind music suffered a marked decline in popularity. In his multi-volume history of the wind band, David Whitwell connects this decline with the rise of Enlightenment philosophy in the late seventeenth century. According to Whitwell, the theological link between wind and spirit supported by the Roman Catholic Church led many listeners to equate wind music with religion. When the rise of humanism challenged traditional religious values, he argues, the corpus of sacred wind instrumental music fell out of popular favor. Brass instruments such as the trumpet and trombone, cornerstones of the sacred instrumental music of the Renaissance and Baroque eras, were put aside in favor of string instruments and updated wind instruments such as the oboe, bassoon, horn, and clarinet. 
Because these new wind instruments lacked symbolic ties to the church, they were readily adopted by Enlightenment-era musicians. Whitwell notes that the "one wind medium which remains associated with the highest levels of society during the Classic Period," the Harmonie band, was comprised entirely of instruments without traditional religious associations. ${ }^{3}$ When allied with a complement of strings, the new Enlightenment-period wind instruments would serve as the nucleus of a new form of musical ensemble, the symphony orchestra.

These newly-introduced wind instruments not only lacked conventional Judeo-Christian spiritual ties, but, in several cases, were derived from Islamic sources. Numerous conflicts between the nations of Eastern Europe and those of the Ottoman Empire over the course of several centuries led to a great deal of social and technological exchanges between cultures. Many of the wind and percussion instruments that would become standard in European ensembles, first in military bands and later in concert orchestras, were re-creations of instruments used by Turkish armies in battle situations. The percussion and reed instruments of the Ottoman military were soon replicated in European bands, which also borrowed the tactics of the enemy in utilizing these instruments on the battlefield.

The Ottoman influence upon subsequent European military practice can hardly be overestimated. The Turkish military invented the concept of the "standing army" in the form of the Yeni cherik, or "New Troops," in 1330, instituting a methodical military structure at a time in which European armies still resembled a loose collection of mercenaries and volunteers. The soldiers of the Yeni cherik were divided into organized regiments, each with designated officers,

\footnotetext{
${ }^{3}$ David Whitwell, The History and Literature of the Wind Band and Wind Ensemble, Vol. 4: The Wind Band and Wind Ensemble of the Classical Period (1750-1800) (Northridge, CA: WINDS, 1982-1991), 2-3. Whitwell asserts, however, that "a last vestige of the former significance" of the sacred winds, particularly the brass, "can be seen in their placement at the top of the orchestral scores of the late Baroque and Pre-Classic Periods" (Ibid.).
} 
non-commissioned soldiers, and staff musicians, all similarly uniformed. ${ }^{4}$ While to the modern observer such structure is a logical aspect of military philosophy, to the European Crusaders who first encountered it, the methodical organization of the New Troops was nothing less than revolutionary. The armies of the West would adopt standing armies of their own, terming their units Janissaries in a mistranslation of the Arabic.

In addition to regimental organization, the Turkish army provided Europeans with an inspirational new model for the effective use of music on the battlefield. Under this system, military music did more than simply inspire the fighting men during a battle. In combat, Turkish musicians were deployed near the army's battle flag, playing continuously throughout the course of the military engagement. This custom provided a clear signal of a battle's progress, with a cessation of the music indicating the loss of the colors and thus defeat. In the Eastern world, the capture of an enemy's musical instruments was tantamount to the capture of the enemy's battle flag. To capture another army's drums signified military glory; to lose one's own drums was cause for shame and disgrace. ${ }^{5}$ Impressed by this practice, European armies adopted the Turkish strategy, incorporating musical ensembles into their fighting forces and stationing them with the battle colors during conflict.

The music of the Yeni cherik was designed to inspire terror and awe, relying heavily on drums and loud reed instruments to create a fearsomely raucous noise. The effectiveness of Yeni cherik's instrumental ensembles was such that Western armies almost immediately adopted each new Turkish instrument they encountered in an attempt to duplicate its terrifying effect. Among the first borrowings were the side drum and kettledrum, derived from the Turkish $t a b l$ and naqqára, respectively; the kettledrum would be commonly referred to as the "tambour des

\footnotetext{
${ }^{4}$ Henry George Farmer, Handel's Kettledrums, and Other Papers on Military Music (London: Hinrichsen Edition, Ltd., 1965), 42.

5 Ibid., 41.
} 
Perses" for almost a century after its European introduction. ${ }^{6}$ Initially the Persian drums were paired with trumpets in both mounted and marching wind bands. By the mid-sixteenth, century, however, the trumpet would lose its battlefield status in favor of the shrill sound of the fife, the first of several Turkish-derived wind instruments to become popular among the European military. Fife-and-drum bands would remain in service throughout Europe over the next few centuries and would become a staple of American military music up to the time of the American Civil War.

The fife was itself replaced by a later Turkish innovation that would become the core instrument of all military wind bands. The zúrná, a reed instrument with a strong, nasal tone, added a new dimension of fearsomeness to the Yeni cherik band's already-impressive sound. The zúrná created a loud buzzing effect that was strongly amplified when its players were grouped in large numbers. Paired with a battery of large drums, a massed zúrná ensemble could intimidate many an opposing army. Tenor and bass versions of the zúrná, known as courtals, added to the din. French armies were among the first to successfully duplicate the tone of the zúrná with the creation of the hautbois, a precursor to the modern oboe. ${ }^{7}$ In French wind ensembles, the hautbois was joined by another new instrument, the bassoon, whose tone was stronger and more reliable than that of the courtal. By 1643 the so-called hautbois band, composed of oboes, bassoons, and drums, had become the standard wind ensemble for all French military units. Within mere decades the hautbois band had become the preferred military band of every European power. ${ }^{8}$

\footnotetext{
${ }^{6}$ Farmer, Handel's Kettledrums, 42.

${ }^{7}$ The word "oboe" is itself an anglicized variant of the French hautbois, refined from such middle-stage spellings as "hautboy" and "hoboy."

${ }^{8}$ Farmer, Handel's Kettledrums, 43.
} 
The introduction of the hautbois ensemble to the English military by Charles II in the aftermath of the English Civil War may serve as good example of how the French model affected military bands in other Western nations. During a period of exile at the time of the British Commonwealth, Charles was introduced to a number of French courtly customs, including the employment of ceremonial wind musicians in the new hautbois band configuration. Upon his return to the British throne, Charles found that instrumental music within the English court had been made virtually nonexistent due to the legislation of Puritan authorities, who had severely limited musical activities within the court and abolished instrumental music from the church. ${ }^{9}$ In reestablishing the British court according to his personal taste, Charles rebuilt the wind ensemble on a new, specifically military, model strongly reflecting the cultural influence of France. ${ }^{10}$ Other official musical ensembles soon followed suit. The first hautbois band in the British military, attached to the Horse Grenadiers in 1678, used instruments bought directly from France. This initial Grenadier band consisted of six oboists and six bassoonists, occasionally accompanied by the unit's military drummers. ${ }^{11}$ Along with the fife-and-drum band, the hautbois ensemble would remain the standard for British music for almost a century, and the designation of military bands as "hautboys" would remain in English vernacular throughout Haydn's time and even into the early nineteenth century.

The English were, in fact, rather late in adopting the model of the French wind ensemble, which had already become the standard across Europe by the time the Horse Grenadiers' instruments arrived. An increased public focus on military events at the start of the eighteenth

\footnotetext{
${ }^{9}$ John Spitzer and Neal Zaslaw, The Birth of the Orchestra: History of an Institution, 1650-1815 (Oxford: Oxford University Press, 2004), 266.

${ }^{10}$ George Henry Farmer goes so far as to say that in Britain, “The 'military band,' as we understand the modern signification of the term," is a direct result of Charles's preference for French-style wind bands (Henry George Farmer, The Rise and Development of Military Music (London: William Reeves, 1912), 44).

${ }^{11}$ Whitwell, The History and Literature, 119.
} 
century, coupled with the Enlightenment-inspired decline of traditional sacred and civic musical institutions, led to a surge in the popularity of military band music. Most new bands reflected the new hautbois model, employing a core instrumentation of oboes, bassoons, and drums. German ensembles extended the sound of their hautbois band by incorporating hunting horns, a practice soon adopted by other countries. A renewed interest in Eastern military tradition several decades later led to the adoption of a whole battery of new "Turkish" percussion instruments within European bands, including cymbals, triangle, and the "Turkish crescent" or "Jingling Johnny," a large pole adorned with bells of various sizes.

In the early eighteenth century a veritable contest of one-upmanship arose between several of the major European powers to see which nation could build the largest and most authentic "Eastern" ensemble. As George Henry Farmer reports, the nations closest to the Ottoman Empire were on the cutting edge of this musical fad:

The credit of having inaugurated the "Turkish Music" novelty belongs to Poland, whose ruler, Augustus II (d. 1733), had received a full Turkish military band from the Sultan. Russia, not to be outdone in this respect, then sought a similar favour from the Sublime Porte, and the Empress Anne (d. 1740) sent a musician to Constantinople in 1725 to obtain a Turkish band, when a combination of some twelve to fifteen performers was secured. ... Following this, Austria adopted the innovation, and in 1741 Ritter von der Trenck marched into Vienna preceded by a Turkish band. . . . By 1770 almost every European army had introduced the above Turkish percussion and concussion $[$ sic $]$ instruments into their regimental bands. ${ }^{12}$

Though performing parts for the "Turkish percussion and concussion instruments" were rarely written out in wind ensemble scores of the time, their presence was generally presupposed. To play up the "exotic" nature of their new percussion instruments, many army units outfitted their drummers in "Oriental" garb, hiring actual Turkish performers if possible. In Britain, the roles

\footnotetext{
${ }^{12}$ Farmer, Handel's Kettledrums, 44.
} 
of "Turkish" percussionists were often taken up by African servants, whose physical appearance and performance style were apparently considered to be sufficiently exotic. ${ }^{13}$

As a fledgling composer in Vienna during the 1750s, Haydn began his career in the midst of the Turkish wind music craze, both aesthetically and geographically. During a brief term as composer in the court of Count Karl Joseph Franz Morzin between 1758 and 1761, and during the early years of his tenure at the Esterházy court, Haydn wrote a number of short instrumental suites for hautbois band. Documentary evidence indicates that Haydn may, in fact, have been personally responsible for the creation of the Esterházy wind band, a possible stipulation of his hiring as Vice-Kapellmeister to Prince Paul Anton Esterházy in 1761. The contract formalizing Haydn's appointment references the concurrent appointment of two oboists and two bassoonists, while other documents from the same month indicate a series of payments made to two horn players who had been in the service of Paul Anton's brother. Furthermore, while a 1759 catalogue of the court's archive makes no reference to any music for hautbois ensemble, a list of "Table and Chamber" musicians, dated June 15, 1761 - just over a month into Haydn's tenure documents an ensemble of two oboes, two horns, two bassoons, and a flute in addition to the court's string players (including Haydn). ${ }^{14}$ If Haydn was not himself responsible for organizing the wind ensemble - or, indeed, the actual hiring of the wind players, as David Wyn Jones suggests - he was at the very least a key figure in its development. ${ }^{15}$

Haydn's original Esterházy wind ensemble was not in actuality a military band but a "field ensemble" created to provide Tafelmusik at dinner and light entertainment during outdoor events, an arrangement common in European courts at this time. This band likely served a similar function to that of a neighboring Feldmusik at the court of one Prince Grassalkovics,

\footnotetext{
${ }^{13}$ Farmer, Handel's Kettledrums, 46.

${ }^{14}$ Whitwell, The History and Literature, 30-31.

${ }^{15}$ David Wyn Jones Haydn. Oxford Composer Companions (Oxford: Oxford University Press, 2002), 437.
} 
which, according to H. C. Robbins Landon, specialized in operatic arrangements, allowing the prince and his guests to enjoy popular music from recent operas outside of the court theater ${ }^{16} \mathrm{~A}$ wind septet of hautbois instruments plus flute would be perfectly suited to such music-making, as its instruments could be heard clearly above dinner conversation and would project adequately outdoors. A small wind ensemble also would be easily transportable for summer visits to country estates.

When not playing dinner music, dance tunes, or operatic transcriptions, the wind players served in the court orchestra. The typical court musician of this time was versatile enough to play at least one string instrument in addition to his primary wind instrument, allowing a nobleman to enjoy a wide array of music without the need of hiring instrumental specialists. When not rehearsing or performing, court instrumentalists were expected to serve in one or more additional capacities within the court bureaucracy, taking on roles ranging from general servant to teacher, secretary, or accountant. The flute, reed, and horn players of the Feldmusik were generally kept separate from the ceremonial trumpeters and drummers, who reported either to a military officer or the stable staff. Like the wind players, trumpeters and drummers were also expected to contribute to the court orchestra, occasionally as string players. $^{17}$

Haydn's earliest wind compositions reflect the format and function of the courtly form of the hautbois band. The surviving repertoire of the composer's wind music from this time consists of a series of short instrumental suites - eleven labeled "divertimenti" and six titled Feldpartie ("field partitas") - that were either written expressly for Prince Esterházy or brought

\footnotetext{
${ }^{16}$ H.C. Robbins Landon, Haydn: Chronicle and Works, Vol. IV: The Years of 'The Creation' 1796-1790 (Bloomington, IN: Indiana University Press, 1977), 21. Landon reports that Prince Grassalkovics would later attempt to hire Haydn to write music for his Feldmusik after the death of Nicolaus I (Ibid.).

${ }^{17}$ Spitzler and Zaslaw, The Birth of the Orchestra, 236-237.
} 
forward from Haydn's brief service in the court of Count Karl Joseph Franz Morzin. ${ }^{18}$ The general style and format of these works suggest that they most likely would have serves as table music or light entertainment rather than as serious concert fare. The majority of the divertimenti and partitas are scored for a traditional hautbois sextet (paired oboes, horns, and bassoons), while some include strings, English horns, or clarinets. The addition of English horn and clarinet, both very new to the European courts of the time, may indicate a later date of composition for some of the divertimenti. ${ }^{19}$ Perhaps Haydn had access to several recentlyinvented instruments and was eager to introduce them to his players, or perhaps he incorporated the extra parts for visiting performers. In either case, the presence of English horns and clarinets at such an early date is notable.

In spite of their perceived status as relative "lightweights" in the Haydn repertoire, the early wind divertimenti may be viewed as key works in the development of the composer's stylistic language. H. C. Robbins Landon observes that the composition of the wind divertimenti and field partitas occupies a historical point “midway in Haydn's attempt to find his own style." ${ }^{20}$ Predating many of the symphonies that would establish Haydn's reputation as a master of orchestral writing, the early wind compositions demonstrate a clear "working out" of compositional challenges. The occasional substitution of clarinets or English horns for the oboes suggests the young composer's experimenting with wind textures. The relatively undemanding divertimento structure may also have allowed Haydn to tackle issues of formal construction on a small scale in preparation for the composition of extended symphonic movements. Landon

\footnotetext{
${ }^{18}$ Scholars continue to debate the proper assignment of the various early wind pieces between the Morzin and Esterházy courts. Though two divertimenti manuscripts bear a compositional date of 1760, suggesting their use at the Morzin courts, they may have been recycled for use in Prince Anton's court. With a newly created Feldmusik in the Esterházy court, it seems unlikely that Haydn would have not provided new music. For a further explanation, see Wyn Jones, Haydn, 437.

${ }^{19}$ Ibid.

${ }^{20}$ H. C. Robbins Landon, The Symphonies of Joseph Haydn (London: Universal Editions and Rockcliff Publishing Company, 1955), 188.
} 
asserts that "the small forms practised in these wind sextets impart to Haydn's style a strength and pithiness which the earlier works usually lack. The experience derived from these windband pieces is also of importance as regards problems of woodwind technique and orchestral colour."21 Though Haydn would later claim not to have mastered wind writing until his old age, these early works demonstrate an early interest in the winds and their possibilities. Because the musicians of the hautbois band were also members of the court orchestra, Haydn's experimentation with wind writing in the divertimenti and Feldpartie would have clear consequences for his wind writing - intended for the same group of performers - in orchestral contexts.

\footnotetext{
${ }^{21}$ Landon, Symphonies of Joseph Haydn, 190.
} 


\section{Harmoniemusik in the European Court: \\ Haydn's Esterháza Symphonies}

Haydn's occasional use of the English horn and clarinet in his early wind divertimenti and Feldpartie reflect a growing trend in European ensembles throughout the early- to mid1700s in which newly created instruments began to be added to the basic hautbois format. The most significant instrumental newcomer by far was the clarinet, widely introduced to European ensembles in the mid-1700s. The clarinet very quickly rose to popularity in a number of military bands and was widely viewed as a worthy companion to - if not a replacement for - the oboe. ${ }^{22}$ A contemporary account depicts a British band's first impression of the instrument: "half a dozen lads of the militia were sent up to London to be taught various instruments to form a military band. The German master Baumgarten put into their hands a new instrument called a 'clarionet' which, with its fiery tone, was better adapted to lead armies into the field of battle than the meek and feeble oboe." ${ }^{, 23}$ The courtal, an even weaker and feebler cousin of the oboe, had already been phased out in favor of a combined horn and bassoon sound; the addition of the clarinet further diversified the tonal color of the wind ensemble. Occasionally joining the clarinet was the serpent, an eighteenth-century predecessor of the ophecleide and tuba that buttressed the bass range. ${ }^{24}$

The introduction of these new instruments to the wind band coincided with an overall shift in aesthetics that accompanied the beginnings of the Classical period of music history, when a blended instrumental texture came to be preferred over that of multiple and distinctive timbres

\footnotetext{
${ }^{22}$ Farmer, Haydn's Kettledrums, 43.

${ }^{23}$ An account by one "W. Gardiner," quoted in Whitwell, The History and Literature, 121.

${ }^{24}$ Farmer, Haydn's Kettledrums, 43-44.
} 
sounding simultaneously in a contrapuntal context. ${ }^{25}$ The European oboe and bassoon already represented a significant softening of the zúrná 's nasal tone; given the accounts of the fearsome racket created by Turkish wind ensembles, it is hard to imagine the original instrument having a "weak and feeble" tone. Horns were added to the hautbois ensemble not to contrast with the double reed color but to blend with it, adding a mellow rather than a harsh brass sound. While the clarinet's "fiery" tone might indeed have added volume and brightness to the hautbois sound, its distinct voice would have contributed to a fuller blended sound without overpowering the other instruments. With the reinforcement of the clarinet, the hautbois band gained new status as a performing ensemble. In many military units, fife-and-drum or all-hautbois ensembles were employed in the din of battle, while newly constituted wind ensembles were reserved for performances of more nuanced and refined music.

In 1763, the clarinet was granted official status within the standard wind ensemble when Frederick the Great issued an order establishing a standard instrumentation of two oboes, two clarinets, two horns, and two bassoons for all Prussian bands. ${ }^{26}$ This combination, known as Harmonie musik, soon became standard across the continent and eventually in England and America as well. As with many hautbois bands, Harmonie ensembles incorporated elaborate batteries of "Turkish" percussion instruments as a complement to the winds. The Harmonie band proved to be a remarkably popular ensemble, and its basic instrumentation would remain more or less unchanged throughout the Classical and early Romantic periods. Like with hautbois bands, the European nobles in charge of various army and court bands soon vied to build the largest and most impressive wind ensemble. This competition would spur the technical

\footnotetext{
${ }^{25}$ David Whitwell insists that the introduction of the clarinet can be seen as the distinct historical delineation point between the Baroque and Classical periods in wind music, asserting that the hautbois band "was in every regard a baroque ensemble" and that the "arrival of the clarinet [defined] the Classic Period of ... military music" (Whitwell, The History and Literature, 119).

${ }^{26}$ Farmer, The Rise and Development, 56.
} 
development and refinement of wind instruments as well as producing a whole generation of accomplished wind performers whose virtuosity raised the capabilities of wind instrument performance.

The Esterházy court quickly adopted the new Harmonie format, a shift spurred in part by a change in patronage. While the Esterházy wind ensemble's activities under Paul Anton had always resembled those of a chamber orchestra rather than a military ensemble, its function changed dramatically after the prince's death in 1762, when his son, Nicolaus I, took power. A decorated war hero with a distinguished record, Nicolaus moved the court to Esterháza, his palace in the Hungarian countryside, establishing a courtly atmosphere reminiscent of an army officer's routine. Quasi-military pomp soon attended many aspects of life at the new estate, with elaborate ceremonies accompanying various daily activities. ${ }^{27}$

At first, the original Esterházy hautbois band took on the responsibility of providing music for these rituals, playing morning serenades and accompanying the ceremonial "changing of the guard." ${ }^{28}$ These duties were eventually transferred, however, to a second wind ensemble created by Nicolaus as an attachment to his personal guard of Grenadiers. A true military band, the Grenadiers' new regimental ensemble of clarinets, horns, and bassoons, took on sole responsibility for parades and other military ceremonies. Evidence suggests that the Feldmusik continued to be active within the court until at least 1780 , presumably reverting to its original function of providing entertainment at dinners and other formal events. ${ }^{29}$ Haydn's duties as a court composer seem to have changed with the addition of the second wind ensemble, as he appears to have written no further divertimenti for Feldmusik. Both the Grenadier band and the Harmonie at Esterháza continued to serve throughout Nicolaus's reign, the importance of their

\footnotetext{
${ }^{27}$ Whitwell, The History and Literature, 36.

${ }^{28}$ The musicians apparently received extra pay for these duties (Whitwell, The History and Literature, 36).

${ }^{29}$ Wyn Jones, Haydn, 437.
} 
status evidenced by the fact that, two days after Nicolaus's death in 1790, his son Anton

dismissed the court orchestra but retained the musicians of the Harmonie. ${ }^{30}$

The Turkish musical practices favored by military bands soon pervaded Nicolaus's

Esterháza court. Housed in the Hungarian countryside rather than in Vienna, the palace was culturally removed from metropolitan Europe and thus more open to outside cultural influences. Eastern European courts like Esterháza continued to lie at the forefront of the "Turkish music" fad due to their geographic proximity to the Ottoman Empire, with relative latecomers in Germany, France, and Britain deriving their Turkish influences second-hand through a VienneseHungarian paradigm. ${ }^{31}$ Although no longer writing explicitly for the wind ensemble, Haydn referenced the influence of Turkish music in a number of symphonic and theatrical works. His “Turkish" opera L'incontro improvisso incorporated many of the aspects that the Viennese associated with Ottoman music: added percussion (bass drum, cymbals, and triangle), duplemeter martial rhythms, and instrumental sonorities designed to create a noisy war-like sound. ${ }^{32}$ Haydn included a Turkish-style military march for Harmonie instruments in his opera Armide, presumably for performance by members of the Grenadier band, who sometimes participated as extras in courtly stage productions. ${ }^{33}$ In the opera Lo speziale, Haydn borrowed from both Turkish and Gypsy sources by including an aria set to a Hungarian dance "in Turkish style" known as the Törökös. ${ }^{34}$ These pieces could not be considered authentically Turkish - or authentically Hungarian, for that matter - but fully Germanic works that employed instrumental and musical "exoticisms" that were held up by European listeners as aural signifiers of the East.

\footnotetext{
${ }^{30}$ Whitwell, The History and Literature, 33.

${ }^{31}$ Farmer, Handel's Kettledrums, 42.

${ }^{32}$ Matthew Head, 'Haydn's Exoticisms: 'Difference' and the Enlightenment," in The Cambridge Companion to Haydn, ed. Caryl Clark (Cambridge: Cambridge University Press, 2005), 78.

${ }^{33}$ Wyn Jones, Haydn, 438. In Armide, the march was performed by an on-stage band; thus the members of the military ensemble functioned simultaneously as actors and musicians.

${ }^{34}$ Head, "Haydn's Exoticisms," 78.
} 
Just as "oriental" clothing on marching band drummers was thought to represent authentic Eastern expression, so too were occasional instrumental, rhythmic, or melodic gestures within an otherwise unexceptional piece heard to signal a distinctly "exotic" character.

Specific information on either the Grenadier band or the Harmonie at Esterháza is relatively sketchy for much of Haydn's time at the court. David Whitwell explains this confusion by noting that "One will find little reference to this ensemble for the years 1766-1790 in Haydn literature, because writers concentrate on Haydn, of course, and not on the rest of the court's activities." ${ }^{35}$ In addition, much more critical ink has been devoted to the numerous symphonies that Haydn wrote for Nicolaus's court than to the various chamber works the composer contributed to Esterháza's musical life. Haydn's increased output of operas and symphonic works likely drew the composer's attention away from works for winds exclusively. The musicians of the courtly ensemble may themselves have been too active in contributing to the court orchestra to provide much wind band music. Many of Haydn's Esterháza symphonies employ a wind section of flute, two oboes, two horns, and two bassoons, suggesting that the Feldmusik ensemble may have increasingly resembled a symphonic wind section rather than an independent chamber ensemble.

In many ways, the evolution of the symphony orchestra and the development of the wind band can be viewed as interconnected events. As new wind instruments were introduced to the orchestra, first in opera pits and later, as the opera orchestra developed beyond the role of stage action accompaniment, in the symphony orchestra, the tonal palette for composers broadened. Wind players were rarely employed in the earliest Baroque operas; in those cases in which wind instruments were required, the players were more likely to appear on stage, in costume, rather than within the core string orchestra. As in Armide, the inclusion of the military band was

\footnotetext{
${ }^{35}$ Whitwell, The History and Literature, 33.
} 
deemed sufficiently unusual to demand extra attention. Eventually, the winds would be included alongside the strings in the main ensemble, at first simply doubling the string parts and later serving as individual voices in their own right. ${ }^{36}$

As the sinfonia opera overture evolved into the concert symphony, the innovations of the opera pit were transferred into concert performance. The inclusion of wind instruments was still enough of a curiosity in the early 1700s to warrant special mention; if a program were to include a symphony or a suite, such as the Water Music, that featured prominent horn passages, for example, advertisements for the concert would invariably make explicit the fact that the work would be performed "with horns." 37 Once this initial novelty passed, advertisements began to focus on performances featuring greater numbers of each instrument, as was the case in a 1758 benefit promising an orchestra boasting four horns rather than the traditional two. ${ }^{38}$ The gradual introduction and acceptance of various wind instruments followed the growth of the hautbois and Harmonie wind ensembles. At first, oboes and bassoons were included with the strings, followed later by horns and flutes. Just as the clarinet would not join the wind band until the mid-1700s, so too would the regular use of clarinets in orchestras lag behind the incorporation of the hautbois core.

Early critics and audience members greeted the introduction of military instruments to the orchestra with skepticism, doubting that any instrument designed for outdoor service could hold its own in a more civilized indoor setting. A typical example of such sentiment comes from the London Morning Herald's review of a 1783 concert:

To those who love trick, and unexpected discovery of what an instrument can perform, Pieltain's horn is a great treat: the French horn is by him made so soft, so

\footnotetext{
${ }^{36}$ Spitzler and Zaslaw, The Birth of the Orchestra, 273. Press, 1993), 88.

${ }^{37}$ Simon McVeigh, Concert Life in London from Mozart to Haydn (Cambridge: Cambridge University

38 Ibid.
} 
voluble, and minute in its modulations, that it might accompany a female voice in a room. ... The horn concerto [performed by] PIELTAIN was surprizing [sic] for such an instrument and was as pleasing as it is possible to render sounds that, singly considered, have so little alliance with what is understood by the term Music. $^{39}$

Oboists and clarinetists faced similar resistance in gaining acceptance on the concert stage. The prominent British clarinet virtuoso, John Mahon, for example, found himself damned with faint praise by the critic who begrudgingly admitted that "Mahon's Clarinet is as well as a Clarinet can be." ${ }^{40}$ Once the core Harmonie instruments were accepted, audiences clamored for more innovation. The piccolo was heralded as new and unusual, as were variants of the oboe (cor anglais) and clarinet (basset horn). The Morning Chronicle once again recounts a typical sentiment, noting that a Subscription Concert featuring one of Haydn's symphonies “was distinguished by the introduction of an instrument called (we know not why) the English horn; the power, tone, and utility of which we are persuaded is highly excellent."41

As new wind instruments, each with new sounds and techniques, were embraced by the concert-going public, virtuoso performing ability became increasingly valued. Initially the simple act of mounting a nuanced performance on a seemingly unwieldy instrument was deemed sufficient cause for critical admiration. Before long, however, performers began to rely on flashy extended techniques to grab the listener's attention. A flautist named Ashe advertised his ability to perform "double notes," the oboist Fischer was applauded for his "ability to swell a very long note from pianissimo to forte and back again," and fellow oboist William Parke promoted his attempts at playing a high $\mathrm{G}$ as if he were attempting to break a world record. ${ }^{42}$ Eventually, the concept of employing wind instruments primarily for interesting effects became

\footnotetext{
${ }^{39}$ McVeigh, Concert Life in London, 88.

${ }^{40}$ Ibid., 89.

${ }^{41}$ David Whitwell, A New History of Wind Music (Northfield, IL: The Instrumentalist Co., 1972), 13.

${ }^{42}$ McVeigh, Concert Life in London, 91.
} 
entrenched in musical composition, as can be observed throughout the symphonic music of the Classical and Romantic eras, in which a majority of works feature the string choir as the core compositional voice with wind instruments adding color on top of the central string sound.

One of Prince Nicolaus Esterházy's most notable achievements was the creation of an impressive opera theater at Esterháza, whose completion greatly changed Haydn's role within the court. The composer's attention now turned to the production of operas and symphonies requiring a full orchestral force rather than the chamber works that had appealed to Prince Paul Anton. The evolution of the courtly wind ensemble can thus be traced through an examination of the numerous symphonies written by Haydn for both Prince Paul Anton and Prince Nicolaus. In the five symphonies attributed to the composer prior to his service to the Esterházys, the only required winds are those of the pre-Classical orchestra: a pair of oboes and a pair of horns. The Baroque continuo is retained in these early works, so a bassoon may have been included in support of the bass line, a circumstance hardly indicative a possible hautbois influence. $^{43}$ In his trio of descriptive symphonies Le Matin, Le Midi, and Le Soir, written as audition pieces for Prince Paul Anton, however, Haydn's writing anticipates the formation of the courtly Feldmusik, calling for a full wind sextet with additional flute. In these symphonies the flute and oboe players take on an unusually high degree of melodic responsibility, perhaps indicating acknowledgement that wind writing was an integral part of the position for which he was applying.

Once Haydn was established in the Esterházy court, his orchestral wind parts would utilize a hautbois format, calling for paired oboes, horns, and bassoons. Strikingly, the flute essentially disappears from Haydn's symphonic scores after being prominently featured in the

${ }^{43}$ All information on Haydn's symphonic orchestration in this section is derived from Appendix I of H.C. Robbins Landon's survey of the Haydn symphonies (Landon, The Symphonies of Joseph Haydn, 615-731). 
three audition pieces. In Symphonies No. 24, 30, and 41, flute is indicated, but only in middle movements, suggesting that the part might originally have been covered by one of the other wind players when needed. On other occasions in which flutes appear, the given symphonies appear to have been written for special events at which extra players were available. This is likely the case with Symphony No. 31 (“The Hornsignal”), which also incorporates an expanded horn section of four players, and the Symphony No. 53 ("Imperial"), which has survived in multiple versions, several of which call for greatly expanded wind forces suggestive of festive occasions requiring the hiring of extra players. It is reasonable to assume that Haydn may have adjusted his orchestration to adapt to varying performance situations when additional visiting musicians may have been temporarily available.

Barring these exceptions, the hautbois format is more or less maintained from Symphony No. 9 through Symphony No. 60. In these works, paired oboes and horns add color to the strings, while bassoons double the string bass lines and occasionally serve as independent wind voices. Trumpets and timpani are called for on occasion, with some scores appearing in two versions, one with trumpet and timpani, one without. Since the court's trumpeters and drummers were attached to the military regiment rather than the prince's musical ensemble, their presence would likely be included when the requisite soldiers were available and absent when those soldiers had more pressing duties. Beginning with Symphony No. 61, the flute, trumpets, and timpani appear to become more or less standard within the symphony, indicating an expansion of the court's wind forces around 1776. While clarinetists were available towards the end of Haydn's Esterházy tenure, the composer does not make use of them in the Esterháza symphonies, though they appear in some of his other works at this time. Haydn would not 
further expand his orchestral palette until he had the opportunity to write for ensembles outside of the court, most notably the orchestras of Paris and London. 
III. The Wind Band Becomes a Concert Ensemble: Haydn's Works for Winds

The introduction of military wind instruments into the symphony orchestra reflected the growing popularity of wind ensemble performances in the early eighteenth century. The military band, at its inception a means for the demonstration of power and authority on the battlefield, had become a favored ensemble for providing ceremonial and "table" music for the nobility. A prince who could boast of an excellent wind band gained considerable status among his peers. As democratic ideals progressed in conjunction with the philosophical Enlightenment, however, the arts became increasingly accessible to a growing middle class, and the wind ensembles of the nobility began to adopt a more public function. Richard Franko Goldman notes that the development of the wind band over the course of the eighteenth century represents the ensemble's gradual evolution “from a private ensemble, hired by a regimental officer for his own pleasure and prestige, to a semipublic institution which provided music for the people at large."44 In some cases, a particular military or courtly band would serve in both a private and a public capacity, providing municipal concerts in addition to its normal service.

Contemporary accounts attest to a growing prevalence of public military band performances across Europe throughout this time. In many cases, Harmonie bands merely accepted responsibilities that had traditionally been given to town musicians in earlier eras. Established wind ensembles were sometimes hired for opera and theater productions on public stages or for church services and civic ceremonies. ${ }^{45}$ The establishment of "pleasure gardens" and other public venues throughout Europe provided a place for outdoor performances that allowed wind ensembles to build a special rapport with people of the common classes.

\footnotetext{
${ }^{44}$ Richard Franko Goldman, The Concert Band (New York: Rinehart and Co., 1946), 36.

${ }^{45}$ Whitwell, The History and Literature, 109.
} 
In Vienna, a number of establishments advertised public concerts by wind ensembles. Richard Franko Goldman suggests that the performances by a particularly notable Viennese ensemble of the time - an 11-piece ensemble consisting of wind octet plus trumpet and drums very well may have been the first "to include percussion for any other than purely military purposes. ${ }^{, 46}$ At first, the musical offerings on such concerts focused on military music, but by the end of the 1700s wind band arrangements of popular tunes, particularly operatic arias, served as popular after-dinner entertainment at a number of public venues. ${ }^{47}$ While the wind ensemble would remain in the shadow of the symphony orchestra on formal concert stages, its popularity in public performances of "light" music - a trend that continues to this day - was firmly established in the eighteenth century.

Various nobles were quick to capitalize on their Harmonie bands' potential as an effective method of building public relations. In London, the Duke of York provided free public concerts in Saint James's Park, featuring his regimental wind octet. In 1783, this octet was replaced by a twenty-four-piece German band imported by the Duke to accompany his Coldstream Guards. The Saint James concerts of the Band of the Coldstream Guards soon became a musical institution, drawing huge crowds and garnering critical acclaim throughout England. ${ }^{48}$ Other wind bands followed suit, spreading good will among the populace while enhancing the status of the patron under whose presumed generosity the ensemble was offered.

As ever, the growth of public bands like that of the Coldstream Guards was spurred in part by competition between various nobles and courts to outdo each other. The consequent growth of the typical Harmonie ensemble is evident in the accounts of various contemporary

\footnotetext{
${ }^{46}$ Goldman, The Concert Band, 34.

${ }^{47}$ Mary Sue Morrow, Concert Life in Haydn's Vienna: Aspects of a Developing Musical and Social Institution. Sociology of Music, no. 7 (Stuyvesant, NY: Pendragon Press, 1989), 160.

${ }^{48}$ McVeigh, Concert Life in London, 92.
} 
military musicians. In Britain's Royal Artillery Band, for instance, the eight contracted wind players showcased their musical versatility by adopting a flexible instrumentation. A report from 1762 indicates that the band "had two cors [=horns], four or five clar[ine]ts, 2 bassoons, 2 oboes, 2 serpents, a flute and a trumpet, with Mr. Wielle [the Master] playing the clarinet.. ${ }^{, 49}$ The band members apparently covered whichever parts were needed for each piece, occasionally borrowing the regimental drummers to fill out the ensemble when their services were not needed elsewhere: "as the Drum Major marched with us we were able to use his drummers and so we had three or four men to spare to play other instruments. ${ }^{, 50}$ The flexibility of this format is evidenced by the remarkable idea that the drummers could be counted on to pick up wind instruments when the situation warranted. As time went on, players and instruments were gradually added to the ensemble, so that by 1805 , the Royal Artillery Band fielded " 26 musicians, counting the drummers etc., 3 Tromboners, 2 Trumpetts, 2 French Horns, 2 Bassoons, 1 Serpent \& 1 Bass Horn, 6 Grand Clarinetts \& 1 Small Clarinett, 1 Small Flute, 3 Hautboys, 1 Long Drum, 1 Small Drum, 1 Tamborin, 1 Cimbals." ${ }^{51}$ The size and virtuosity of the local military band soon became a source of civic pride, adding to the prestige of the entire community in addition to its wealthier patrons.

The rise to prominence of the military band in public circles throughout Europe reflected a gradual change in the nature of the army during the eighteenth century. Where armies of earlier times had been mustered only in times of war or were created as guard units for particular noblemen, standing military units of the eighteenth century began to be viewed as servants of the public good. National armies came to symbolize cultural identity and patriotism rather than the

\footnotetext{
${ }^{49}$ Quoted in Farmer, Handel's Kettledrums, 25. The name of the bandmaster points to a common trend in early British military ensembles, the hiring of foreign - almost always German - directors.

${ }^{50}$ Ibid.

${ }^{51}$ From a contemporary description, quoted in Farmer, Handel's Kettledrums, 4; this document also mentions the presence of "Janissary Bells."
} 
glory and power of the ruling monarch. ${ }^{52}$ The success of the military was linked to the fortunes of the people, and military heroes became idolized as national icons. Thus, increased interest in military wind bands was due in part to the novelty of the ensemble and in part to a rising demand for music that heralded national military success. In many contemporary public concerts, the band's offerings were accompanied by the singing of patriotic songs whose lyrics referenced current military engagements and exhorted heroism and victory.

Military bands also represented a new spirit of communal participation by relying on civilian musicians to fill the ranks. While a few key regiments in a given country's army might be staffed by enlisted military personnel, many units fielded ensembles of non-rostered wind players. ${ }^{53}$ In most cases, regimental bands functioned as private musical ensembles, paid for by the officers of the regiment and functioning at their whim. ${ }^{54}$ For civilian musicians, participation in an army band provided numerous performance opportunities and a steady salary. As an added benefit, eighteenth-century rules of engagement did not classify civilian musicians as hostile soldiers, sparing bandsmen from a great deal of jeopardy in wartime. ${ }^{55}$ A position in the local military band would look quite desirable to accomplished instrumentalists looking for job security.

Raising a civilian band provided advantages for the rest of the regiment as well. A tongue-in-cheek outline of the potential benefits of an army band for the rank-and-file foot soldier can be found in an anonymous document from 1782 entitled "Advice to Officers of the British Army:"

${ }^{52}$ Spitzler and Zaslaw, The Birth of the Orchestra, 518.

${ }^{53}$ George Henry Farmer reports that in eighteenth-century Britain, "excepting the Royal Artillery, the Life Guards, the Horse Guards, the Horse Grenadier Guards, and the Foot Guards, all 'Bands of Musick' in the army were unofficial, although tolerated" (Henry George Farmer, Military Music. World of Music, no. 10 (London: Parrish, 1950), 29).

${ }^{54}$ Whitwell, The History and Literature, 125.

${ }^{55}$ Ibid., 127. 
If your regiment should not be provided with a band of music, you should immediately persuade the captains to raise one. This, you know, is kept at their expense, whilst you reap the principal benefit; for besides keeping them always with your own company, and treating them as your private band, they will, if properly managed, as by lending them to private parties, assemblies, etc., serve to raise you a considerable interest among the gentlemen of the country, and, what is more, among the ladies. ${ }^{56}$

The benefits of a regimental band were not limited to units within the standing army. A number of town militias began to raise their own instrumental ensembles, even in small rural communities. The popularity of these civic militia bands was such that much of the extant military wind music from the eighteenth century comes not from the repertoires of the professional officer corps but from the collections of "unofficial" small-town ensembles. ${ }^{57}$ Increased civilian participation in the military and in military musical ensembles helped to build a sense of communal ownership in the wind band. Fielding an accomplished military ensemble was no longer a source of pride among nobles only; it was quickly becoming an outlet for civic pride and national patriotism as well.

The democratization of military wind music was heightened by the events surrounding the French Revolution, as the menace of impending chaos created a vast surge of patriotism in many nations, attended by a virtual explosion in the popularity of military band performances. A huge new repertoire of marches and patriotic songs for winds appeared on the European market, breaking new ground in the process. As David Whitwell has discovered,

This body of music is of more than routine interest for several reasons. First, most of these marches were published in full scores and are the earliest such publications in the history of music - dating a full generation, or two, before the orchestral scores of the early nineteenth century, to which traditional literature assigns this honor. These scores also include the earliest examples of printed percussion parts, often in graphic notation - as if one were not quite sure how to notate these sounds! ${ }^{58}$

\footnotetext{
${ }^{56}$ Qtd. in Whitwell, The History and Literature, 125.

${ }^{57}$ Ibid., 129.

${ }^{58}$ Ibid., 130.
} 
The inclusion of full scores allowed amateur directors to quickly and efficiently organize their ensembles without needing to master all of the written parts prior to rehearsal and performance.

When the rise of Napoleon precipitated formal war in Europe, the military band gained an even greater foothold in the public consciousness. David Whitwell notes that "the majority of all extant titles of eighteenth century English military music" date from the 1790s, immediately following Britain's formal declaration of war against France. ${ }^{59}$ To further broaden their civic appeal, many of the leading marches of the time were published with an added version for harpsichord and flute, allowing the musically accomplished citizen to perform these works in the home. $^{60}$ Thus, military music became a truly democratic form of popular music, performable by musicians of all rank and social class. As one contemporary observer noted in a description of a patriotic band concert, "nothing could be more consonant to the present warlike spirit that universally prevails."

Though the bulk of Haydn's attention was drawn to the composition of operas and symphonies during his service to Nicolaus Esterházy, several of his works for wind band from this period have survived. The earliest is a march from Act one, scene four of the opera Armide. The most performed opera at Esterháza - purportedly Prince Nicolaus's favorite - Armide recounts the tale of a soldier who is seduced by a sorceress and distracted from his patriotic duties. ${ }^{62}$ Haydn's musical depiction of the military man Rinaldo draws upon many of the windband conventions of the time. Horns and timpani accompany Rinaldo's first aria, with prominent wind accompaniment further heightening musical allusions to the soldier's life. The March,

\footnotetext{
${ }^{59}$ Whitwell, The History and Literature, 129.

${ }^{60}$ Ibid., 130-131. British publishers were quick to adapt this practice to the wildly popular works of Haydn; all of the "London" Symphonies were printed in home versions scored for string quartet, flute, and (optional) piano (Christopher Hogwood, Haydn's Visits to England (London: The Folio Society, 1980), 96).

${ }^{61} \mathrm{McV}$ eigh, Concert Life in London, 112.

${ }^{62}$ H. C. Robbins Landon, Haydn: Chronicle and Works, Vol II: Haydn at Esterháza 1766-1790 (Bloomington, IN: Indiana University Press, 1978), 551.
} 
scored for a sextet of winds (paired clarinets, horns, and bassoons), was performed by the Grenadier band as an on-stage feature within the drama. Though composed for a staged opera, the March's rhythmic style and formal construction are typical of contemporary works for Harmonie ensemble. It is highly conceivable that the Grenadier band incorporated the March as part of its standard field repertoire.

A second march from the Esterházy period is the Marche Regimento de Marshall, written for the military band of Count Ernst Dietrich Marschall. This march was likely given as a gift to Marschall by Prince Nicolaus, whose son Anton served as a regimental commander in Marschall's service from 1767 through the 1770s. ${ }^{63}$ As court composer Haydn would have been expected to provide the music for any such Princely gift. The Marche Regimento de Marshall is the only authentic Haydn march known to have been written for a neighboring court, though other such pieces may have been written and subsequently lost.

The March in E Flat, Hoboken VIII:6, may also have come from the time of Haydn's service to Prince Nicolaus, though scholars appear to be divided on the issue of the work's actual date of composition. Although some scholars have used anecdotal evidence to suggest that the march might belong to the Haydn's London period, the majority of musicologists place the work within the period of the composer's service to Prince Nicolaus. This view is clearly that of the venerable Haydn-Institut of Köln, which includes the March in E Flat twice within their opera omnia collection of Haydn's work, once among the general collection of wind marches, and once in the appendix to the score of Armide. ${ }^{64}$ An examination of the March in E Flat alongside the march within Armide does not seem to suggest a direct correlation, particularly as the Armide

\footnotetext{
${ }^{63}$ Wyn Jones, Haydn, 437.

${ }^{64}$ Franz Joseph Haydn, Tänze und Märsche, Joseph Haydn Werke, series V. (Munich-Duisburg: G. Henle Verlag, 1995), 207; Franz Joseph Haydn, Armida: Dramma Eroico. Joseph Haydn Werke, series XXV, vol. 2. (Munich-Duisburg: G. Henle Verlag, 1965), 316.
} 
march is in the key of $\mathrm{C}$, and melodically unrelated to the March in E Flat. The inclusion of the March with the opera's score would seem to suggest, however, that the scholars of the Joseph Haydn Institut, at least, believe the work to date from the same period as Armide.

If the March in E Flat was not commissioned for the Grenadier band at Esterháza, it was likely the product of one of Haydn's two visits to London during the 1790s. While the early marches (like the wind divertimenti and Feldpartie) were written at the pleasure of the prince as a service of the court composer, Haydn's London-era marches resulted from independent commissions. In the latter years of his service to Prince Nicolaus, Haydn's contractual restrictions were loosened somewhat, allowing the composer to explore commissions outside of Esterháza. Upon Nicolaus's death in 1790, Haydn was permitted to travel, opening new and more lucrative career opportunities abroad. During his two London journeys at the behest of the impresario Johann Peter Salomon, Haydn composed twelve symphonies that cemented his reputation as "father of the symphony." Surrounding these works, about which much has been written by musicologists throughout the ages, are a number of smaller commissioned works that have received much less critical attention. Included in this subset are several marches for the Harmonie- era military wind band.

Haydn's popularity by the time of his London voyages was such that many works were spuriously attributed to him at the time. Though a number of short tunes were erroneously attributed to the composer, three complete marches can be definitively traced to Haydn during the London period: the March for the Prince of Wales (Hoboken VIII:3) and the Two Marches for the Derbyshire Cavalry (Hoboken VIII:1 and VIII:2) ${ }^{65}$ The former work dates to Haydn's first London visit, the latter to his second. H. C. Robbins Landon suggests 1792 as a likely

\footnotetext{
${ }^{65}$ The full title page for the Derbyshire marches reads "Two Marches for Sir Henry Harpur, Bart, and presented by him to the Volunteer Cavalry of Derbyshire."
} 
origin date for the March for the Prince of Wales, based in part on the existence of an orchestral arrangement of the march whose autograph is dated from later that year. ${ }^{66}$ Like Nicolaus Esterházy, the future George IV seems to have fielded both a Tafelmusik chamber group and a personal military band. The March for the Prince of Wales appears to have been written for the larger military band; the trumpets, serpent, and percussion called for by Haydn would not likely have been available within the courtly Harmonie ensemble. ${ }^{67}$

Despite its military instrumentation, however, the March for the Prince of Wales demonstrates a compositional refinement that would indicate its proper setting to be the concert room rather than the field. After a strong unison opening, Haydn introduces a chamber-music texture with a clarinet and bassoon duo presenting a lyrical answer to the opening fanfare. The solo players are instructed to play this passage cantabile (e piano). The contrast between forceful, unison statements and soft, thinly-scored chamber passages is an element distinctive to this march, setting it apart from Haydn's other military marches. While the two Derbyshire marches, for instance, also contrast piano and forte dynamics, the musical texture remains consistent throughout. In the March for the Prince of Wales, on the other hand, Haydn's piano sections call for soloistic chamber playing whose nuance would be lost in an outdoor performance. Another unique element of the March for the Prince of Wales is the inclusion of a trio, a feature notably absent from Haydn's other wind marches, including the Armide march. This section is marked piano throughout, serving as a distinctive point of contrast for a presumably military march. As H. C. Robbins Landon points out, the March for the Prince of

\footnotetext{
${ }^{66}$ Landon, Haydn Chronicle III, 488.

${ }^{67}$ Whitwell, The History and Literature, 85.
} 
Wales “is, actually, a very unmilitary March,",68 a view supported by the piece's chamber orchestration and formal structure.

Haydn himself seems to have recognized the suitability of the work for concert performance; when commissioned by the Royal Society of Musicians for a short orchestral piece, he merely copied the March for the Prince of Wales, adding an extra trumpet part and incorporating new flute and string parts to fill out the orchestration. The added instruments simply double the original wind parts without alteration or transposition. Haydn apparently was successful in presenting the orchestrated march as a newly composed work, entitling it Grand March composed expressly for and presented to the Royal Society of Musicians, London. Whether Haydn felt that the members of the Royal Society were unlikely to hear the prince's march or that they would forgive his musical recycling is unclear. His reuse of material seems to have been less an act of deception than a fast and easy solution to an incredibly crowded compositional schedule. At the time of the Royal Society commission, the composer had become so busy as to put various friends to work as emergency copyists. It is conceivable that the simple translation of the March for the Prince of Wales into a new work with extra doubled parts might have been the kind of project Haydn could pass off on a subordinate. ${ }^{69}$

The other two marches from Haydn's London period were composed as a set and were commissioned by the newly-mustered Derbyshire Cavalry. This local volunteer unit was formed in 1794 by county sheriff Sir Henry Harpur, who personally requested the two marches from Haydn and funded their publication. ${ }^{70}$ Haydn completed the two pieces in 1795 , according to the

\footnotetext{
${ }^{68}$ Landon, Haydn Chronicle III, 488.

${ }^{69}$ Landon goes so far as to speculate that Haydn's friend and correspondent Rebecca Schroeter may have done the copy work for the Grand March (Landon, Haydn Chronicle III, 157).

${ }^{70}$ Landon, Haydn Chronicle III, 260.
} 
dated autograph that has survived for the first of the two marches. ${ }^{71}$ The Two Marches for the Derbyshire Cavalry thus postdate Haydn's other British military works, including the "Military" Symphony.

The Derbyshire Marches are also the most functional of Haydn's works for wind band, their musical content indicating their purposes in field maneuvers. The first march, in E flat, is thickly scored, with the entire band playing similar melodic material in unison rhythms. The second march, in $\mathrm{C}$, is more transparently scored, though the writing is not as soloistic as that in the March for the Prince of Wales. The reason behind the differing textures appears to be functional, with the first march apparently intended to be played while on horseback and the second while dismounted. ${ }^{72}$ The Two Marches for the Derbyshire Cavalry also demonstrate Haydn's "tailoring” of the musical material specifically for the abilities of Harpur's players. A musical motif found in both Derbyshire marches but in no other of Haydn's marches is a triplet rhythm in the trumpet working against dotted figures in the other instruments. This crossrhythm, unusual for trumpet parts in military music of the time, and unique among Haydn's works for winds, may well represent Haydn's highlighting of a particularly accomplished trumpeter in Harpur's band. ${ }^{73}$

The care with which Haydn crafted marches for Harpur and his ensemble in the midst of an incredibly busy compositional schedule is evidence of the respect that Haydn held for military men, a trait that can be observed throughout the composer's life. Military culture would certainly have been close to Haydn's heart, given his strong loyalty to the war hero Prince Nicolaus. Perhaps his work with the Grenadier band gave the composer extra insight into the world of the professional soldier. In any case, Haydn was clearly comfortable in the presence of

\footnotetext{
${ }^{71}$ Landon, Haydn Chronicle III, 260.

${ }^{72}$ Whitwell, A New History, 14.

${ }^{73}$ Landon, Haydn Chronicle III, 489.
} 
military men, as numerous anecdotes about the composer attest. Contemporary biographer Albert Christoph Dies relates the story of a chance meeting between Haydn and some Prussian officers during the composer's second trip to London. On his way from Vienna, Dies reports, Haydn stopped at an inn in the town of Wiesbaden, where he overheard some Prussian officers, "all great admirers of his music," performing an excerpt from one of Haydn's symphonies on the piano in an adjoining room. When Haydn introduced himself, the soldiers initially refused to believe that he was the famed composer. When Haydn eventually produced documentation proving his identity, however, the officers entertained Haydn "till long past midnight," by which point, Dies claims, "Haydn was loath to leave his new-found friends.",74

Both Dies and fellow biographer Georg August Greisinger record stories of French soldiers visiting Haydn during the siege of Vienna in the latter years of the composer's life, reporting that the composer proved just as friendly toward French soldiers as he had been with Austrian, German, and English soldiers. The biographers reference several of the visitors by name, most notably a pair of French military musicians named Maret and Soult. ${ }^{75}$ Dies provides the rather sentimental account of a visit by another French officer named Sulimi, whose impromptu performance of a tenor aria from The Seasons is reported to have brought Haydn to tears. "Both men became so emotional," Dies writes, "that they were seized with a violent trembling, which kept the Captain at his departure from writing his name legibly. ${ }^{76}$

\footnotetext{
${ }^{74}$ Albert Christoph Dies, "Biographical Accounts of Joseph Haydn, According to His Spoken Narration," in Joseph Haydn: Eighteenth-Century Gentleman and Genius, ed. Vernon Gotwals (Madison, WI: University of Wisconsin Press, 1963), 167-168. This story is representative of a large repertoire of Haydn anecdotes in which the composer must prove his identity to strangers who refuse to believe that the humble man before them could possibly be the celebrated composer Haydn.

${ }^{75}$ Dies, "Biographal Accounts," 118; also Georg Ugust Griesinger, "Biographical Notes Concerning Joseph Haydn," in Joseph Haydn: Eighteenth-Century Gentleman and Genius, ed. Vernon Gotwals (Madison, WI: University of Wisconsin Press, 1963), 57. Though Dies does not actually name the officers, editor Vernon Gotwals strongly contends that they are "the shadowy Maret and Soult" mentioned by Greisinger (Vernon Gotwals, Joseph Haydn: Eighteenth-Century Gentleman and Genius (Madison, WI: University of Wisconsin Press, 1963), 244, n. 50.

${ }^{76}$ Dies, "Biographical Accounts," 193.
} 
Sir Henry Harpur himself has been linked by some scholars to one of the most popular and most frequently retold stories within a large body of popular and frequently-told Haydn anecdotes. According to Dies, while Haydn was in London, a mysterious soldier visited him to commission a pair of marches. When Haydn attempted to beg off of this commission, citing a heavy work schedule, the soldier produced a large roll of gold coins, at which point an agreement was reached. At the appointed time, the officer returned to Haydn's apartment to hear the results. After Haydn performed the first march (in the key of E flat, according to Dies's account), the soldier abruptly rose to his feet, grabbed the manuscript, and, leaving his money, walked to the door, refusing to hear Haydn's playing of the second march. "It can't possibly be better than the first," Dies quotes. "Farewell! Tomorrow I sail for America." Derbyshire marches were written explicitly as a set, with the first march in the key of E flat, many scholars assume that the mystery officer in Dies's anecdote must be either Harpur himself or another musician of his regiment. ${ }^{78}$ David Wyn Jones identifies the anonymous commissioner as one "Charles Francis Greville, brother of Sir Henry, though he is not known to have been a member of the regiment himself;" the evidence underlying this assertion is unclear. ${ }^{79}$ Since no evidence seems to link either Harpur or his regiment to America, his correlation to the mystery officer in Dies's account is tentative at best.

The identities of the marches in the anecdote have also spurred speculation. David Whitwell suggests that the original piece must be the March in E Flat generally been attributed

\footnotetext{
${ }^{77}$ Dies, "Biographical Accounts," 149-150. In an alternate telling, the officer is headed to India rather than America, and Haydn destroys his second march manuscript when it is refused (Landon, Haydn Chronicle III, 73).

${ }^{78}$ This is certainly the opinion of Vernon Gotwals, who adds a footnote in his translation of the Dies text to explicitly tie the excerpt to the Derbyshire marches (Gotwals, Joseph Haydn, 249-50, n. 83).

${ }^{79}$ Wyn Jones, Haydn, 438. Several factors undermine the Harpur (or surrogate) theory, most importantly the fact that Haydn is depicted by Dies as working on the score to Orfeo, which was abandoned in 1791; Harpur's regiment was not formed until 1794.
} 
to Esterháza. Whitwell thus assigns the march, and the anecdote, a date of $1793 .{ }^{80}$ Assuming that Dies's story is not a total fabrication, the identity of the mysterious marches (and the mysterious soldier) may never be uncovered. Of course, it is quite plausible that neither of the marches mentioned by Dies have survived. According to the story, the first manuscript apparently went to America (or India, in another telling), and the fate of the second march is left untold. Regardless of the true details of this oft-told tale, Haydn's affinity with soldiermusicians of diverse rank and nationality would seem to indicate an ongoing familiarity and comfort with military bands and performers.

One of the composer's most noted military admirers was the greatest of British naval heroes, Lord Horatio Nelson. Haydn was also a Nelson admirer, and the 1800 meeting between composer and general during Nelson's visit to Vienna sparked the public's imagination. The two celebrities exchanged gifts, Nelson making a present of his watch to Haydn in return for one of the composer's used pens. ${ }^{81}$ Haydn set to music several parts of a poem entitled "The Battle of the Nile" that had been written by one of Nelson's traveling companions in celebration of the general's most recent military victory. ${ }^{82}$ Nelson attended several Haydn performances during his stay in Vienna, possibly including the premiere performance of the Te Deum. He also attended a performance of the composer's most recent Mass, a work which consequently became widely known as the "Nelson Mass" in honor of the event. ${ }^{83}$

Several other marches, or fragments of marches, have also been occasionally proposed as having been written by Haydn in London. A March in C and a March in D, both attributed to Haydn, occasionally appear in the composer's list of works, though both seem to be spurious;

\footnotetext{
80 "For lack of better evidence, we may assume this is that march" (Whitwell, A New History, 15).

${ }^{81}$ Griesinger, "Biographical Notes," 57.

${ }^{82}$ Landon, Haydn Chronicle IV, 561.

${ }^{83}$ Ibid., 562.
} 
neither is included in the Hoboken catalogue. ${ }^{84}$ An undated fragment, containing the initial eight bars of an additional March in E-Flat, clearly belongs to Haydn's London period, but remains unfinished. This fragment might represent an early sketch for the March for the Prince of Wales or the beginning of a new work whose circumstances remain a mystery. ${ }^{85}$ Haydn also arranged and published the wildly popular second movement of the "Military" Symphony for wind band, allowing the piece to take its place on pleasure garden concerts with a broader audience than those found in the Hanover Square Rooms.

One additional march comes from the post-London period: the Hungarian National March, Hoboken VIII:4, written in 1802 at the request of Jacob Hyrtl, an oboist in the Esterháza wind band. ${ }^{86}$ Though the composer was still technically obliged to the Esterházy family on a part-time basis, the Hungarian March represents a gift to the courtly wind players rather than a contractual fulfillment. Haydn's continued warm feelings toward the military musicians at the court are evidenced not only by the gift of a new march but also by some evident tailoring of the work to this specific group of musicians. A comparison of the march's early drafts show that Haydn created an alternate version of the first oboe part in m. 26 that allowed the player to choose between a very rhythmic option and a simplified option with easier rhythms. H. C. Robbins Landon suggests that this built-in flexibility might represent "the last dying echoes of that improvised performance practice that flourished in Baroque times," but this assertion seems to be a stretch, describing, as it does, a march written in $1802 .^{87}$ The extra options seem more

\footnotetext{
${ }^{84}$ Whitwell, A New History, 15.

${ }^{85}$ H.C. Robbins Landon claims the former, asserting that the sketch appears to be "the first draft, or Urversion, of the March for the Prince of Wales" (Landon, Haydn Chronicle III, 488-89). The instrumentation of the sketch is the same as that of the prince's march, but the rhythms and melodic shape, though somewhat similar, do not appear to demonstrate a direct correlation.

${ }^{86}$ Whitwell, A New History, 14.

${ }^{87}$ H. C. Robbins Landon, Haydn: Chronicle and Works, Vol. V: Haydn: the Late Years 1801-1809 (Bloomington, IN: University of Indiana Press, 1977), 241.
} 
likely to reflect Haydn's concern to create a work that Hyrtl, a fellow musician and, presumably, a friend, could perform comfortably with his ensemble.

An additional nod to the band's unique situation comes in a number of stereotypically "Gypsy"-related musical gestures meant to evoke the court's Hungarian locale. While the march as a whole lacks a level of exotic coloring to be labeled a character piece or a piece of folk music, several tell-tale gestures are notable. In his survey of Haydn's musical "exoticisms," Matthew Head observes the melodic inclusion of cadential motif known as the "Kuruc fourth" in addition to a number of rhythmic syncopations linked to a purportedly Hungarian folk style. ${ }^{88}$ As with the Derbyshire marches' triplet figures, written to highlight a particular trumpeter's abilities, the "Gypsy" elements of the Hungarian National March emphasize the unique qualities of an individual military band. Haydn's success in this musical evocation is clearly indicated by the "National" designation added by appreciative listeners to the march's title.

${ }^{88}$ Head, "Haydn's Exoticisms," 91. 
IV. Military Music and the Sublime: Haydn's “London” Symphonies

The connection between the eighteenth-century wind band and the Classical-period symphony orchestra may not initially seem obvious to a twenty-first century observer, yet the aesthetics of the military and of the symphony were considered quite compatible at the time. In fact, as John Spitzler and Neal Zaslaw note in their study of the historical development of the orchestra, the idea of orchestra-as-army was " $[b] \mathrm{y}$ far the favorite metaphor for the orchestra in the eighteenth century." ${ }^{\prime 89}$ This analogy was not unique to Haydn's time but could be traced at least as far back the Baroque period. In J. A. Birnbaum's 1739 essay in support of Johann Sebastian Bach's instrumental music, the author argues that "If an entire army can be trained so that at a given sign one sees many thousand men carry out a maneuver as though they were a single man, then the same precision ought to be even more possible in a musical ensemble, which consists of many fewer persons. ${ }^{, 90}$ Nearer to Haydn's time comes this 1791 opinion by Francesco Galeazzi: "Nothing is more beautiful than to experience the perfect unity that is to be found here and to see with what uniformity all the bows move. It is exactly like watching military maneuvers by well-trained and disciplined troops. Such orchestras fully reward both the eye and the ear." ${ }^{, 91}$ If such military metaphors were considered apt for the string section, the inclusion of military wind instruments to the orchestra could only further the perceived connection between the army and the orchestra.

The rise of the symphony orchestra coincided with the development of revolutionary new military tactics throughout Europe. In the past, mercenary soldiers had been hired for specific campaigns, their training focusing solely on the achievement of a focused set of specified goals.

\footnotetext{
${ }^{89}$ Spitzler and Zaslaw, The Birth of the Orchestra, 515

${ }^{90}$ Ibid.

${ }^{91}$ Ibid., 515-516.
} 
The development of the standing army in the late-seventeenth and early-eighteenth centuries placed greater emphasis on constant battle readiness. As infantry tactics increasingly relied on the coordination of well-trained units maneuvering in formal columns and ranks, coordination and discipline became emphasized as the most vital elements of battle planning. Consequently, weapons and marching drills became important components of military training. A distinct benefit to these drills was that they could be easily displayed in public. Thus, a well-trained and drilled army, its marching and maneuvers coordinated by military music, became, like the orchestra as described by Galeazzi, a pleasure to both the ears and the eyes. ${ }^{92}$

In many ways, the precision of the parade drill belied the true nature of war. No matter how well-trained the troops or well-formed their ranks, war was, and is, a chaotic and fearful enterprise. The horrors of war fell into line with one of the preeminent aesthetic concepts of the eighteenth century: the Sublime. In the early Romantic period of literature and art, the category of the Sublime was proposed as the polar opposite of the aesthetic category of the Beautiful. While a beautiful subject could hold the observer's attention thanks to its excellent and virtuous qualities, a sublime subject was thought to be equally compelling, yet frightening and terrible. The early Romantic depiction of the Sublime included concepts of the irrational, the natural, and the chaotic, appealing to irrationality and disorder. Artistic beauty was held to stimulate contemplation, but artistic sublimity was thought to rely on sheer and immediate emotional affect. ${ }^{93}$ The challenge facing an artist portraying the Sublime was to depict its chaotic and terrifying aspects while maintaining the formal conventions required by good artistic taste. The correlation to the military and its music is unmistakable. The ordered rank and file of the eighteenth-century army, represented by the structured music of the standard march form,

\footnotetext{
${ }^{92}$ Spitzler and Zaslaw, The Birth of the Orchestra, 517.

${ }_{93}$ Mark Evan Bonds, "The Symphony as Pindaric Ode," in Haydn and His World, ed. Elaine Sisman (Princeton, NJ: Princeton University Press, 1997), 140.
} 
demonstrated logic and rational planning placed in the service of the terrifying and chaotic violence of warfare.

Haydn's knack for combining unerring formal logic with musical material dripping with the Sublime was a crucial factor in his success as the preeminent symphonist of the day. The musicologist of the twenty-first century must put aside the pall of "Classicism" attached to Haydn by later aestheticians in order to comprehend the full impact of the composer's sublime Romanticism. To the critics of his day, Haydn's music depicted unchecked emotion, masterfully contained - but barely so - within the composer's artful forms. A contemporary poem by

Thomas Holcroft memorably presents this view of Haydn's art:

\section{TO HAYDN}

Who is the mighty master, that can trace

Th'eternal lineaments of Nature's face?

'Mid endless dissonance, what mortal ear Could e'er her peal of perfect concord hear?

Answer, Oh, HAYDN! strike the magic chord!

And as thou strik'st, reply, and proof afford.

Whene'er thy Genius, flashing native fire, Bids the soul tremble with the trembling lyre, The hunter's clatt'ring hoof, the peasant-shout, The warrior on-set, or the battle's rout, Din, clamour, uproar, murder's midnight knell, Hyaena shrieks, the warhoop scream and yell All sounds, however mingled, strange, uncouth, Resolve to fitness, system, sense and truth!

To others noise and jangle; but to thee

'Tis one grand solemn swell of endless harmony.

When dark and unknown terrors intervene, And men aghast survey the horrid scene, Then, when rejoicing fiends flit, gleam and scowl, And bid the huge tormented tempest howl; When fire-fraught thunders roll, and whirlwinds rise, And earthquakes bellow to the frantic skies, 'Till the distracted ear, in racking gloom, Suspects the wreck of worlds, and gen'ral doom; 
Then HAYDN stands, collecting Nature's tears,

And consonance sublime amid confusion hears. ${ }^{94}$

In this description, the symphony-as-army metaphor is extended beyond notions of precision of movement and into the realms of aesthetics. The second stanza of Holcroft's poem, in particular, demonstrates the direct correlation in the poet's mind between Haydn's symphonic music and a heroically grand terror specific to military conflict.

The great skill attributed to Haydn in this poem, namely the ability to control the chaotic elements of the Sublime in a skillfully ordered manner, was also prized by eighteenth-century critics of the visual arts. Paintings depicting grand battle sequences became extremely popular in the 1790s, particularly in Great Britain, where Haydn, not coincidentally, produced the most dramatic of his symphonies. Epic battle paintings, like Haydn's symphonies, combined elements of chaos and order, contrasting images of disciplined fighting men in the background with foreground depictions of death and bloodshed. A prime example of such art, and a painting that provides interesting parallels with Haydn's "Military" Symphony in particular, is Benjamin West's famed depiction of the death of General James Wolfe at the Battle of Quebec. West's painting might be considered the visual equivalent of Haydn's "Military" Symphony.

As Dennis Montagna notes in his study of this painting, West's image is but one of a number of portraits depicting the death of General Wolfe, a historical event that held special relevance to British citizens of the 1790s. Though the Battle of Quebec had taken place in North America over a decade before West began his painting, the idea of a heroic soldier giving his life in battle against the French had renewed meaning in the era of Napoleon. With a new war with France brewing in Europe, "Britons enthusiastically embraced Wolfe's memory and cast him as a national martyr. At the same time, they viewed the battle that had taken Wolfe's life as 94-95.

${ }^{94}$ Originally printed in the Morning Chronicle, September 12, 1794. Quoted in Hogwood, Haydn's Visits, 
decisive in elevating British self-esteem and as a focus for anti-French sentiment."95 In this particular depiction, the dying Wolfe lies fainting in the foreground, surrounded by characters whose faces display grief but whose bodies are staged in manneristic and unrealistically staged poses. In the background, the battle rages, but in a manner organized in such a way that individual images can be read as "a narrative of the entire battle of Quebec" with an attention to detail that "indicates that much painstaking research and careful planning must have gone into its creation." $" 96$ A knowledgeable observer would be able to recognize the city of Quebec and to trace the course of the battle by scanning the background events from the left to the right side of the canvas.

Montagna asserts that when "examining the painting in relation to the historical facts of the Battle of Quebec, it becomes clear that West staged Wolfe's death as the culmination of a vast, continuous narrative depiction of the entire battle." 97 Thus, West's presentation combines the drama of a heroic death in the midst of violent warfare with a studied historical authenticity presented within a formal narrative structure. Just as Haydn's music, in Thomas Holcroft's estimation, presented the "warrior on-set, or the battle's rout" while maintaining aesthetic consonance, so too did West's painting stimulate the British public with a sublime image masterfully presented.

The link between West's The Death of General Wolfe and Haydn's symphonic aesthetic is not merely speculative. Indeed, historical evidence demonstrates that Haydn viewed the painting in person during a visit to Carisbrooke Castle on the Isle of Wight, where he also likely

\footnotetext{
95 Dennis Montagna, “Benjamin West's The Death of Wolfe: A Nationalist Narrative," American Art Journal, 12 (Spring, 1981): 80.

${ }^{96}$ Montagna, "Benjamin West's The Death of Wolfe," 85. Montagna notes that the key difference between West's The Death of General Wolfe and other paintings of the same subject is its high degree of geographic and historic authenticity, with all secondary characters arrayed in the correct battle uniforms.

${ }^{97}$ Ibid., 73.
} 
handled the various items owned by Wolfe - including personal papers, an Indian sash, and the general's side arms - that were kept at the castle in the manner of religious relics. He could not have overlooked the painting's overwhelming popularity; copies of the work were hung in art dealers' shops throughout Britain. ${ }^{98}$ West's painting was one of the most popular works of visual art in its day, and it maintains its iconic status to this day.

Haydn likely observed a number of other paintings of the same nature, as the patriotic atmosphere of 1790s Britain provided the perfect market for depictions of battle heroism. John Singleton Copley's dramatic painting of the Siege of Gibraltar was placed in a permanent display pavilion not far from the oft-visited home of Rebecca Schroeter in 1791. Thomas Tolley suggests that, given the pavilion's proximity, Haydn must certainly have been one of the 60,000 people who paid the entrance fee of a shilling to view the painting firsthand. ${ }^{99}$ Another battle painting that was notably displayed before a paying London public during Haydn's visit was Phillip James Loutherbourg's gigantic canvas The Grand Attack at Valenciennes. Representing a more current military engagement against the French, in this case the 1793 victory of a joint British and Austrian force under the command of the Duke of York, The Grand Attack displayed the same type of studied authenticity that distinguished Benjamin West's painting of The Death of General Wolfe. ${ }^{100}$ Haydn had the opportunity to meet Loutherbourg in person, an event the composer thought sufficiently notable to warrant inclusion in the third of his London notebooks.

Haydn's encounter with Loutherbourg occurred during the composer's journey to Portsmouth, where he had the chance to step aboard a recently-captured French warship. The

\footnotetext{
${ }^{98}$ Thomas Tolley, Painting the Cannon's Roar: Music, the Visual Arts, and the Rise of an Attentive Public in the Age of Haydn, c. 1750 to c. 1810 (Ashcroft, England: Ashgate Publishing Company, 2001), 220-221.

99 Ibid., 250. Haydn had created his own artistic depiction of Gibraltar in the Esterháza opera L'assedio di Gibilterra in 1783.

${ }^{100}$ Ibid., 251. In this case, the artist had not only visited the battlefield, but also had employed an assistant to sketch the faces of the battle's commanders and their uniforms, creating what was widely considered an authentic portrait of the fighting. Tolley notes that the chronological proximity of the painting's unveiling to the premiere of the "Military" Symphony must have “colored” the London audience's perception of Haydn's masterpiece.
} 
British military seems to have held a particular interest for Haydn as an observer of culture. His London notebooks are full of detailed descriptions of military forces and equipment, with tantalizing references to social contacts buried amidst veritable litanies of arcane facts concerning the number of decks, masts, and cannons included on various British warships. The aforementioned reference to the meeting with Loutherbourg is tossed, almost as a non sequitur, into Haydn's account of the day: “...The ship is terribly shot to pieces. The great mast, which is 10 feet 5 inches in circumference, was cut off at the very bottom and lay stretched on the ground. A single cannon-ball, which passed through the captain's room, killed 14 sailors. I met Lauterburg $[s i c]$, the famous painter." 101 Haydn's disappointment in being barred from a visit to the Portsmouth Dockyards - the composer having been deemed a security risk as a foreigner - is almost palpable as he records the snub in his notebook. ${ }^{102}$

The authorities in Portsmouth need not have feared Haydn's potential as a foreign spy; his interest in the patriotic fervor sweeping England was but one example of the composer's keen observation of cultural elements that could be adapted into his musical language. In his exploration of these elements in Haydn's composition, Matthew Head notes the depth of Haydn's engagement with outside cultural influences: "Crucially, [Haydn] does not crudely 'Other' such materials, that is, he doesn't present them simply as exotic curiosities. Instead, he treats them as topics and as melodies that can participate fully in the musical discourse."103 From his cultural vantage point of the Hungarian Esterháza court, Haydn had borrowed melodic material from the folk tunes of the Hungarians, Croatians, and other ethnic people of the area. ${ }^{104}$

\footnotetext{
${ }^{101}$ From the third London Notebook; H.C. Robbins Landon, The Collected Correspondence and London Notebooks of Joseph Haydn (Fair Lawn, NJ: Essential Books, 1959), 292.

${ }^{102}$ Betty Matthews, "Haydn's Visit to Hampshire and the Isle of Wight, Described from Contemporary Sources," Haydn Yearbook 3 (1965): 113.

${ }^{103}$ Head, "Haydn's Exoticisms," 79.

${ }^{104}$ H.C. Robbins Landon also mentions Haydn's consciousness of "the vast domain of Slavonic folkmusic" in his study of the composer's symphonies (Landon, The Symphonies of Joseph Haydn, 263).
} 
Head notes that Haydn's use of such materials "understates their exoticism," integrating them within the context of Western European art music in an “'advanced' and technologically sophisticated" manner. ${ }^{105}$ Likewise, military themes - musical and associative - that might seem foreign to the civilized concert hall find a place amidst Haydn's most artistically-developed symphonies. In writing his later symphonies, Haydn became increasingly aware of his need to reach a specific audience, particularly in works written for audiences beyond the court of Prince Nicolaus. His symphonies gradually incorporated elements of drama, with important concepts conveyed through the quotation of specific melodies or styles that would be easily recognizable to his listeners. ${ }^{106}$

Without a strong British art music tradition from which to draw inspiration during his visits to London - his most notable "English" compositional forerunners being fellow Germans like George Friedrich Handel and Johann Christian Bach - Haydn found his inspiration in the popular music of the time. The London-era wind marches demonstrate this concern, as does the composer's lengthy set of arrangements of historic Scottish and Celtic folk music, written at the same time. ${ }^{107}$ Haydn had many opportunities to hear military band music and to observe displays of militant patriotism amongst the English populace.

References to wind bands occur at several points in the composer's London Notebooks, usually in relation to specific meals or other occurrences. Often, the ensemble's presence is noted casually; for instance, Haydn records in 1792 that "I went with Mr. [William] Fraser up the Tems [Thames] from Westminster Bridge to Richmond, where we ate on an island. There were

\footnotetext{
${ }^{105}$ Head, "Haydn's Exoticisms," 79. Head specifically cites Haydn's use of two Croatian folk tunes in the slow movement of Symphony no. 103. By incorporating such folk material in a display of sophisticated compositional technique, Head argues, Haydn honors the original source material by demonstrating the appropriateness of "ethnic" melodies for "traditional" symphonic treatment (Ibid.).

${ }^{106}$ David P. Schroeder, "Orchestral Music: Symphonies and Concertos," in The Cambridge Companion to Haydn, ed. Caryl Clark (Cambridge: Cambridge University Press, 2005), 97.

${ }^{107}$ Head, "Haydn's Exoticisms," 78.
} 
24 persons in our party, besides a Feld Music."108 In other instances the band's presence is quite notable, as in Haydn's report of a more rousing event from 1792: "Lord Clermont . . gave a large Soupé and when the King's health was drunk, he ordered the wind band to play the wellknown song, 'God save the King' in the street during a wild snowstorm."109 Though he attributed the display in part to alcoholic overindulgence, the impromptu performance stuck in his memory.

By the time of his second visit, the patriotic spirit in London had reached the level of mob mentality. As Haydn details, "On $11^{\text {th }}$ June [1794] the whole city was illuminated because of the capture of 7 French warships; a great many windows were broken. On the $12^{\text {th }}$ and $13^{\text {th }}$ the whole city was illuminated again. The common people behaved very violently on this occasion. In every street they shot off not only small but also large guns, and this went on the whole night. ${ }^{110}$ Haydn seems to have been bemused by, rather than apprehensive of, such exuberance; H.C. Robbins Landon suggests that, in general, "Haydn thought the English slightly mad."111 Mad or not, the British populace was enamored by the success of its national military, displaying an enthusiastic patriotic spirit upon which Haydn would draw for inspiration in writing his last, and greatest, symphonies.

The connection between this military enthusiasm and Haydn's symphonic depictions of the Sublime is most notable, unsurprisingly, in the Symphony No. 100, which continues to bear the popular nickname "the Military." The symphony's popular subtitle appears to have come from Haydn himself, as the composer, without apparent prompting, refers to the work as "the Military Symphony" in recounting a May 4, 1795 performance within the pages of one of his

\footnotetext{
${ }^{108}$ From the second London Notebook; Landon, The Collected Correspondence, 275.

${ }^{109}$ From the second London Notebook; Landon, The Collected Correspondence, 276.

${ }^{110}$ From the third London Notebook; Ibid., 287

${ }^{111}$ Landon, Haydn Chronicle III, 73.
} 
London notebooks. ${ }^{112}$ Though the programmatic elements of this symphony made it an instant audience favorite, a status the work has maintained to the present day, the conceit of the work was not unusual for its time. Indeed, "battle symphonies" enjoyed a brief vogue during the 1780s and 1790s, feeding on the emerging aesthetic preference for the Sublime in a tense political era. Because most of these works depicted the details of specific military engagements, with elaborate program notes recounting the action of the battle being portrayed, their topicality generally doomed them to quick obsolescence. ${ }^{113}$ The over-the-top theatricality of some of these works must have been impressive to behold, however.

Among the more notable examples of late eighteenth-century "battle pieces" were Johann Friedrich Klöffler's staged conflict between two separate orchestras in 1783; Ignazio Raimondi's "Battle" Symphony of 1784, whose movements depicted the pre-battle maneuvers and planning, a battle sequence, cries of the wounded, and a triumphant victory celebration; and composer named Mazzinghi's controversial The Siege of Bangalore of 1793, written a bit too close to the aftermath of the French Revolution for some contemporary critics. ${ }^{114}$ The grandest spectacle of them all may have been a presentation at the Drury Lane Theater in London, staged in the aftermath of General Howe's naval victory. As Christopher Hogwood describes it, "the pièce de résistance was a sea-fight between two model fleets, which slid in from opposite wings and engaged in gun-fire: patriotically 'the spectators coughed and enjoyed the powder.",115 Many "battle symphonies" faced accusations of banal writing and vulgar sensationalism, and many demonstrated inferior compositional construction. Those that survived - including Haydn's

${ }^{112}$ A. Peter Brown, The Symphonic Repertoire, Vol. II: The First Golden Age of the Viennese Symphony: Haydn, Mozart, Beethoven, and Schubert (Bloomington, IN: Indiana University Press, 2002), 279.

${ }_{113}^{113}$ Morrow, Concert Life, 156-57.

${ }^{114}$ McVeigh, Concert Life in London, 116-117.

${ }^{115}$ Hogwood, Haydn's Visits, 87. 
"Military" Symphony and Dussek’s "Grand Military Concerto" (C. 153) - demonstrated a high degree of compositional craftsmanship in addition to their strictly programmatic elements.

Haydn was a first-hand observer of the "battle symphony" phenomenon at least once during his initial London visit. The London Morning Herald of February 2, 1792 includes the review of a benefit concert performance at which "[t]he celebrated Battle piece of Mr.

RAIMONDI, went off with its usual applause." The same review notes that "[w]e particularly, and with pleasure, remarked the two great heroes of the ensuing musical campaign, we mean Messrs. HAYDN and PLEYEL, sitting together all the evening, not as contending rivals, but Chiefs associating in the same pursuit." 116 That pursuit appears to have been a gauging of audience taste. The fruits of Haydn's observation would be most tangibly demonstrated in his own "Military" Symphony, though the composer's efforts to exploit the tastes of the public can be traced in all of his "Paris" and "London" symphonies.

Haydn's scrutiny of the military patriotism sweeping Britain during the 1790s - as shown in popular audience preference for the aesthetic sublime, in painted representations of war exhibited to an eagerly paying public, in visits to shipyards full of captured enemy vessels, in the ebullient playing of "God Save the King" by a band in a blizzard, and in Raimondi's "Battle" Symphony - led him to tailor his symphonies in accordance with the spirit of the time. Audiences and critics did not fail to make this connection. In one of the earlier London symphonies, No. 94 - the famed "Surprise" Symphony - listeners had connected on several levels with the sudden forte that disturbs the otherwise peaceful texture of the Adagio movement. According to one newspaper critic, "the surprise might not be unaptly likened to the situation of a beautiful Shepherdess who, lulled to slumber by the murmur of a distant Waterfall, starts

${ }^{116}$ Landon, Haydn Chronicle III, 130, punctuation original. 
alarmed by the unexpected firing of a fowling piece."117 While not a directly military metaphor, the likening of the forte to a gunshot may suggest that such a connection was not far from the listeners' minds. Strikingly, another connection with the visual arts can be found in the "surprise." Thomas Tolley observes that "the shepherdess and the fowler" scenario reflects the popularity of pastoral scenes in paintings of the time, also suggesting that what "may have been Haydn's starting point for his desire to surprise on this particular occasion, as many in the audience may have recognized, was a painting exhibited at the Royal Academy in 1791 entitled simply Surprise. This was one of a long series of self-portraits by the prominent French painter Ducreux illustrating various expressions." "118 If Tolley's surmise is accurate, the success of mimicking a popular painting's affect in the "Surprise" Symphony may well have encouraged Haydn to adopt a similar process in capturing the spirit of The Death of General Wolfe, The Siege of Gibraltar, and The Grand Attack at Valenciennes in fashioning his own "battle piece," the Symphony No. 100 ("Military").

Haydn clearly penned his hundredth symphony with a battle scenario in mind, composing the picturesque Allegretto with its military allusions first. Manuscript evidence demonstrates that Haydn composed the Minuet movement next, completing the more characteristic movements before beginning work the formally-composed outer movements. ${ }^{119}$ This working order seems to contradict the rules of Classical-era symphonic construction, in which dramatic weight is most often contained within the first and fourth movements, with the middle movements generally portraying a lighter felling. However, Haydn was a composer who knew his audience. Simon McVeigh's observes that in Haydn's day, “[t]he British prided themselves on their good taste in

${ }^{117}$ Quoted in A. Peter Brown, "The Sublime, the Beautiful, and the Ornamental: English Aesthetic Currents and Haydn's London Symphonies," in Studies in Music History Presented to H. C. Robbins Landon, ed. Otto Biba and David Wyn Jones (London: Thames and Hudson, Ltd., 1996), 55-56.

${ }_{118}$ Tolley, Painting the Cannon's Roar, 248-49.

${ }^{119}$ Landon, Haydn Chronicle III, 558. 
the cultivation of the Adagio." ${ }^{120}$ Cognizant of this fact, Haydn saved his most overt musical trickery - the "Surprise" forte, the ticking of "The Clock" - for his symphonic slow movements, where they were more likely to charm London audiences.

In the "Military" Symphony, the slow movement evokes the battlefield through Harmonie-style wind writing, military percussion instruments, and a trumpet call heralding the moment of battle, which is itself musically represented by a crashing minor chord punctuated by a loud timpani roll. Interestingly, the wind band theme upon which the Allegretto is based is not original to the "Military" Symphony but a transcription of the second movement of an earlier Haydn work, the Concerto No. 3 (VIIh:3) for two lires, two violins, two violas, and continuo, written for the King of Naples in $1786 .{ }^{121}$ In the "Military" Symphony this material is transformed from a lyrical "Romance" (as it is designated in the concerto) into a fairly convincing march tune. With a trumpet call and stormy coda appended, the lire's music loses its concerto identity, fitting seamlessly into the context of a military march.

The Allegretto's orchestration is the key element by which Haydn evokes his military scenario. Making use of the larger complement of wind players available to him in London than had been at Esterháza, Haydn employed wind voicings similar to those in his marches for military band. The wind orchestration of the Allegretto proved to be sufficiently comparable to band scoring to warrant the production of second version of the movement for Harmonie ensemble. After the phenomenal success of the symphony's premiere, Haydn was quick to realize the potential for the military movement's success both on the concert stage and the in the field. The task of arranging the Allegretto for winds was remarkably easy; Haydn more or less

${ }^{120}$ McVeigh, Concert Life in London, 140.

${ }^{121}$ Landon, Haydn Chronicle III, 558. Perhaps because this movement is primarily the reorchestration of another piece, the autograph for the second movement has not survived with the rest of the "Military" Symphony's manuscript (Ibid.). 
copied the symphonic wind parts for a Harmonie ensemble of paired flutes, clarinets, bassoons, and horns, plus trumpet, serpent, and Militärinstrumente (percussion). ${ }^{122}$ While contemporary newspaper accounts do not record audience reaction the wind band version of the Allegretto from the "Military" Symphony, it is hard to imagine the arrangement failing to be a success in light of the symphony's overwhelming effect on London audiences.

The addition of field percussion to the symphony orchestra, highly unusual for the time, signaled military imagery to its audience just as clearly as though a fully-dressed marching band had literally tramped onto the stage. Some critics found this aspect of the symphony to be somewhat distasteful. A critic for the Morning Chronicle included this caveat within his otherwise glowing review of the work: "We cannot help remarking, that the cymbals introduced in the military movement, though they there produce a fine effect, are in themselves discordant, grating, and offensive, and ought not to have been introduced, either in the last movement of that Overture, or in the Finale at the close of the Concert." ${ }^{23}$ Tasteful or not, the utilization of a full wind ensemble and the incorporation of percussion were universally recognized as symbolic of war, even if the thematic material came from a distinctly non-military source. Thomas Tolley suggests that Haydn may have reorchestrated the lire concerto theme in a conscious attempt to draw listeners' attention to the orchestration. ${ }^{124}$ If the audience was at all familiar with the music of the lire concerto, the switch to a wind-based instrumentation would have been quite noticeable.

The orchestration alone would have been sufficient to suggest a military atmosphere in the minds of British listeners, yet Haydn made the battle reference even more overt through the

122 Brown, The Symphonic Repertoire, 281.

${ }^{123}$ Landon, Haydn Chronicle III, 250-51. In a subsequent review of a later concert performance, the same critic complains not of the inclusion of the percussion but of its execution: "the Drummer and Cymbol-player [sic], who are principal actors in the piece, instead of beating, most cruelly murdered the time" (Ibid.).

${ }^{124}$ Tolley, Painting the Cannon's Roar, 251 
addition of the coda to his original lire concerto movement. The trumpet call that signals the beginning of this coda may, in fact, reference an actual military fanfare of the time, though the original identity of the melody has eluded scholars. ${ }^{125}$ Regardless of whether or not the identity of the trumpet fanfare was immediately recognizable to Haydn's listeners, its implications as an unmistakable battlefield referent were clear. The subsequent crescendo of the timpani roll, leading to a crashing full-orchestra fortissimo, could only be heard as the chaos following the battle call.

Contemporary listeners did not miss the point. One reviewer suggests that in this passage "what may well be called the hellish roar of war increase[s] to a climax of horrid sublimity!",126 Indeed, this climactic chord marks the moment that truly defines the "Military" Symphony's battle metaphor. The music from the lire concerto and the trumpet fanfare are heard, in retrospect, as preparations for the crashing coda; they become preliminary scenes that, in one contemporary critic's words, "mark and tell the story." The critic outlines the story of the Allegretto movement: in its wind orchestration, the now-martial lire theme "inform[s] us that the army is marching to battle," with the subsequent coda material "calling up all the ideas of the terror of such a scene, give[s] it reality. Discordant sounds are then sublime; for what can be more horribly discordant to the heart than thousands of men meeting to murder each other."127 The discordant Sublime drew audiences in droves much in the same was as the displays of huge war paintings like The Death of General Wolfe. Tapping into the same public sentiment, the "Military" Symphony became an instant public success. The work was performed eight times on

${ }^{125}$ Landon, Haydn Chronicle III, 563. Landon suggests that the trumpet motif is "clearly an 'Allied' fanfare" of either British or Austrian origin. German scholar Arnold Schering claims Haydn's fanfare to be a forerunner of the Prussian cavalry's "Paradepost" fanfare, which remained in use up to the early days of World War II (Ibid.).

${ }^{126}$ Landon, Haydn Chronicle III, 247, punctuation original.
${ }^{127}$ Ibid., 250-251. 
Peter Salomon's concert series, and in every performance, newspaper reports indicate, the second movement was encored amidst overwhelming applause. ${ }^{128}$

The influence of military music upon Haydn's hundredth symphony was not limited to the picturesque Allegretto. The Minuet, whose autograph indicates an earlier date of composition than either of the outer movements, appears to have been written specifically as a companion to the Allegretto, so that the two middle movements would form the dramatic core of the symphony. ${ }^{129}$ The Minuet's initial tempo marking of Moderato seemingly indicates a slower tempo than those of Haydn's typical symphony minuets. Several scholars have detected in this slower speed a possible allusion to military drill, or, as Thomas Tolley describes it, a "whiff of military precision." ${ }^{\prime 130}$ In addition, the Trio section of the movement employs dotted rhythms that mirror similar patterns in Haydn's marches for wind band. H. C. Robbins Landon finds a further, more sinister, implication in these dotted rhythms, drawing a correlation to the traditional long-short patterns of the French overture, which would seemingly indicate a veiled reference to "the enemy across the Channel."131 Whether an evocation of French musical style or of military music in general, the rhythmic writing serves as a continuation of the metaphor that distinguishes the Allegretto.

With the aesthetic emphasis on the Sublime in art works of the late eighteenth century, dramatic features within the "Military" Symphony's outer movements can also be read as further signifiers of an overall military metaphor. Thomas Tolley reads the twin climaxes of the opening movement's development section as having "the potential to call to mind the surging of troops." Tolley also suggests that "[b]oth principal subjects in the first movement may be shown to carry

\footnotetext{
${ }^{128}$ These reports can be found throughout Landon's Haydn Chronicle III.

${ }^{129}$ Landon, Haydn Chronicle III, 558-59.

${ }^{130}$ Tolley, Painting the Cannon's Roar, 251-52.

${ }^{131}$ Landon, Haydn Chronicle III, 563.
} 
implications of armed forces." ${ }^{\prime 132}$ At the close of the symphony's final movement, Haydn reintroduces the "Turkish" percussion, though the music can hardly be perceived as a battlefield scene at that point. Among the few negative critiques that greeted the symphony after its premiere was the complaint that this final burst of percussion was unsuited to the joyful mood in which the work concludes. In the words of one contemporary audience member, "in the march of the second movement, the 'military' instruments were consonant with its character; for the jig of the finale, they were clearly inappropriate." ${ }^{\prime 13}$ The seemingly obvious interpretation of this musical effect, that it might indicate a joyful military triumph, seems to have escaped the critics of that embattled time.

While the Symphony No. 100 contains Haydn's clearest allusions to military music within his symphonies, evidence of the prevalent British military spirit can be detected throughout the full set of twelve "London" Symphonies. Thomas Tolley looks to the slow introductions to the opening movements of the late symphonies for further examples of Haydn's capturing the tense political situation of a nation at war:

In the slow introductions to the symphonies of Haydn's last London season, for example, the music has a more searching and intense quality compared with the previous symphonies, shared by those sections of the slow movements in minor keys. Their unsettling harmonic shifts, with the principle interest often in the lower parts, resulting in darker, more mysterious textures, set the compositions as entities in the context of an uncertain world. ${ }^{134}$

These elements tie directly into the aesthetic of the Sublime, building upon the composer's socalled Sturm und Drang style that had been demonstrated in several of the Esterháza symphonies. However, given the predilection for military imagery in the British arts of the period, not to mention the visual and musical works of composers throughout Europe, Haydn's

\footnotetext{
${ }^{132}$ Tolley, Painting the Cannon's Roar, 251-52.

${ }_{133}$ Qtd. in Brown, "The Sublime, the Beautiful, and the Ornamental," 55.

${ }^{134}$ Tolley, Painting the Cannon's Roar, 253.
} 
"darker, more mysterious textures" may represent, even more than the direct imagery of the "Military" Allegretto, the response of a composer to a world at war.

In the patriotic atmosphere of England in the 1790s, Haydn's exploration of the drama of the symphonic form found a uniquely sympathetic audience. His late symphonies were immediate blockbusters, with the "Military" Symphony leading the surge of popular acclaim. Within a decade, the Symphony No. 100 had been published by multiple firms in London and Paris, with editions coming from the leading publishing houses in Germany and Austria, and Holland as well. ${ }^{135}$ This phenomenal success was in no small part due to Haydn's careful observation of his cultural surroundings, his sophisticated use of musical symbols that would easily be grasped by the audience, and his ability to utilize the instruments of the contemporary wind ensemble to their full effect.

${ }^{135}$ Landon, Haydn Chronicle III, 559. 


\section{The Decline of the Courtly Wind Ensemble: Haydn's Late Masses}

While Haydn was enjoying remarkable success in England, changes in the Esterházy regime were affecting both the status and the quality of music at the court. While Prince Nicolaus had been an ardent patron of the arts who had truly valued Haydn's services, his son Anton was less concerned with the maintenance of a world-class musical program. Upon Nicolaus's death in 1790, Anton disbanded the court orchestra and opera company as a costcutting maneuver. Haydn's duties were curtailed to a more or less ceremonial role in which the composer was responsible for providing occasional works for the court while otherwise being free to seek his fortunes elsewhere. While it is easy in retrospect to criticize Anton's seemingly cavalier dismantling of one of Europe's most iconic private musical programs, such actions were by no means unique to the Esterházy court. The system of artistic patronage that had supported the arts for over a century was passing in favor of new public art organizations like the Salomon Concerts under which Haydn's late symphonies were funded and premiered. Like the wind band, the orchestra was evolving from a private institution of the nobility to a publicly sponsored ensemble available to listeners of every class. With the costs of the Napoleonic wars mounting, noblemen like Prince Anton could no longer afford to fund their own court orchestras.

The abolition of the court orchestra did not mean the end of music at Esterháza; both the Harmonie ensemble and the Grenadier band were retained by Anton for the duration of his short reign. The situation would once again change in 1794, however, with the death of Prince Anton and the accession of his son, Nicolaus II. The new prince almost immediately disbanded the courtly Harmonie, leaving the Grenadier band as the only remaining instrumental ensemble at 
Esterháza. ${ }^{136}$ The motivation for this move appears to once again have been a financial one. Nicolaus II apparently did not wish to take on the expense of maintaining a courtly musical ensemble. The Harmonie players at Esterháza had enjoyed a relatively comfortable life under the system of noble patronage. Though the musicians retained servant status and continued to be responsible for some menial work in addition to their performance activities, they were relatively well paid and had opportunities to do some freelance work on the side. The members of the Grenadier Band, on the other hand, received a far lower standard of pay and were hired under more prohibitive military contracts that allowed few liberties. By disbanding the Harmonie, the new prince could order the Grenadier musicians to undertake the same performances at a much smaller cost.

The musical life of the court no longer resembled the glory days of the 1760s, when Esterháza boasted one of Europe's finest opera theaters on site, led by one of the world's most noted composers. By 1794, Haydn was essentially gone, maintaining some small duties to the court but otherwise making music entirely on his own; the opera and orchestra were no longer functioning; and the only remaining musical ensemble was comprised of soldiers rather than favored servants. Just as Haydn had moved from the esteem of a position as court composer to the relative uncertainty of a life as a self-promoting independent composer, upon the accession of Nicolaus II the wind players of Esterháza were forced to leave the comfortable world of patronage to take on the lives of freelance musicians. This transition was, of course, not unique to this particular group of performers. Throughout Europe, music was shifting from the courts to the public sphere, significantly changing the role of the wind instrumentalist. Where woodwind and brass players of the Renaissance, Baroque, and Classical periods had generally held key 22.

${ }^{136}$ Roger Hellyer, “The Wind Ensembles of the Esterházy Princes, 1761-1813," Haydn Yearbook 5 (1984): 
positions in courts and the church, serving in orchestras as a secondary role to their primary functions, by the 1790 s and the early 1800 s wind performers were beginning to take jobs primarily as members of symphonic wind sections, perhaps participating in wind music on the side every now and then. A Romantic emphasis on the symphony as the ultimate musical statement led to the subordination of the winds to the larger symphonic orchestra, where its onceunique sound was blended with that of a large string choir.

At courts like Esterháza, however, the wind band continued to flourish despite the loss of their more prestigious wind players. The Eisenstadt Archives contain a large collection of wind music parts and scores belonging to the court's ensembles from the 1790s through the early 1800s. The size and breadth of this collection attest to the continuing popularity of wind music at Esterháza during the reigns of both Anton and Nicolaus II. Both princes appear to have used the wind band as a sort of low-budget orchestra. In addition to a number of original wind partitas, the archives contain wind arrangements of many orchestral and operatic works, including full versions of several of Mozart's operas. ${ }^{137}$ Esterházy musician Georg Druschetzky arranged many of Haydn's works for the Grenadier players, including unabridged versions of The Seasons and The Creation with wind band accompaniment. ${ }^{138}$ Under Nicolaus II, the band undertook the concert performance of such music in addition to its various military functions.

The burden of these dual roles appears quickly to have worn on the members of the Grenadier band, who came to feel that the situation was less than fair. In 1798 the wind players pressed for a higher salary more representative of their efforts; the prince responded by dissolving the Grenadier Band. Roger Hellyer, in his historical survey of the Esterházy wind

${ }^{137}$ Landon, Haydn Chronicle IV, 21.

${ }^{138}$ Whitwell, The History and Literature, 37. The comprehensive nature of these arrangements is indicated by the sheer size of the individual parts; the first oboe part for The Creation, for instance, takes up 45 pages of manuscript (Ibid.). 
ensembles, suggests that Nicolaus II may have been unable to provide extra funding for the band due to his financial obligations to the war effort. ${ }^{139}$ However, the prince appears to have imported wind players from Vienna during the Grenadier Band's hiatus, and he eventually reinstituted a courtly Harmonie in November of 1800, hiring strictly civilian musicians, casting doubt on this claim. ${ }^{140}$ With the rise of professional orchestras during the early nineteenth century, Nicolaus II may have been unable to competitively hire the sort of ensemble that his namesake Nicolaus I had enjoyed. With a lower-budget wind ensemble and a library of orchestral and operatic transcriptions, however, the court could continue to provide concert music in spite of the financial difficulties caused by the Napoleonic wars.

After the death of Nicolaus I in 1790, Haydn's ties to the Esterházy court had become largely nominal, continued more in honor of the late prince than because of Haydn's loyalty to his successors. During the London years, Haydn had the opportunity to explore new avenues of composition; his encounters with British society and the success of the twelve "London" Symphonies inspired new aesthetic possibilities for the aging composer. As Haydn wrote to a colleague upon returning to Vienna, "I have only just learned in my old age how to use wind instruments, and now that I do understand them, I must leave the world."141 Fortunately for his adoring audiences, Haydn had enough years remaining to compose a number of new masterpieces, many in genres that the composer had previously left unexplored. Indeed, the final "London" Symphony would prove to be the composer's last.

${ }^{139}$ Hellyer, "The Wind Ensembles," 29.

${ }^{140}$ Ibid., 32. Hellyer continues his speculation on the prince's war finances by suggesting that the promptings for the reestablishment of the Harmonie remain unknown, supposing that "perhaps the expenses of the war were easing somewhat." This explanation does not explain the prince's apparent "constant importing of [musicians] from Vienna," a project that Hellyer says "was proving increasingly uneconomic" (Ibid.).

${ }^{141}$ Whitwell, A New History, 13. 
Haydn's new-found understanding of wind writing was gleaned through the practice of composing for wind bands and for the orchestras of London, which boasted larger wind ensembles than Haydn had ever had at his disposal at Esterháza. At the court, his choices of winds had been limited to the instruments and players that were at hand. In England, Haydn was able to employ, for the first time, a full orchestral woodwind section. He had the freedom to use whatever wind scoring he wished and, thanks to the virtuosity of the British professionals, to attempt more exposed wind passages. He took particular advantage of the possibilities of a full wind section in his final six symphonies, utilizing the woodwind and brass players to their maximum effect.

Upon his final return to Austria, Haydn began to seek out opportunities to further enhance his wind-writing techniques. One of his first major projects was the revision of an instrumental work based on the seven last words of Christ. The new choral version of the Seven Last Words incorporated an added text superimposed upon the original musical material, which was itself expanded into a full orchestral treatment. However, the section of the new Seven Last Words that appears to have brought Haydn the most satisfaction was an instrumental interlude for wind band that serves as the Overture to the work's second half. After composing this new movement, the only section consisting of new music not derived from the original work, Haydn declared the updated Seven Last Words "the best I ever wrote in my life." Contemporary music publishers echoed this opinion; Breitkopf and Härtel advertised the work as having been "entirely enriched by a new piece for wind instruments," and the Pressburg Zeitung of November 17, 1801 dubbed the Overture "a great new work for wind instruments." Overture, Haydn makes use of the full complement of symphonic winds of the time, excluding

\footnotetext{
${ }^{142}$ Whitwell, The History and Literature, 37. Such opinions were not limited to the critics of Haydn's day; H. C. Robbins Landon declares the wind Overture to have been "one of Haydn's most original and brilliant tours de force" (qtd. Ibid.).
} 
trumpets. The scoring calls for the Harmonie core of a flute, two oboes, two clarinets, two horns, and two bassoons, buttressed by two trombones and contrabassoon. The score order demonstrates that Haydn's thinking is focused on the wind band rather than the symphony orchestra, as the bassoon lines are placed at the bottom of the score, beneath those of the trombones. This format acknowledges the bassoon's role as the bass instrument in a Harmonie band without serpent. The score order is completely appropriate for a wind band composition but appears somewhat awkward in an orchestral context. By purposefully scoring the Overture in the order of a Harmonie band, Haydn clearly indicates that the movement should be considered a composition for wind ensemble rather than an orchestral piece with tacet strings.

Also from 1796 comes a second winds-only movement included within a larger work: the Arie de Schutzgeistes (Aria of the Guardian Spirits), one of several incidental selections accompanying the play Alfred, König der Angelsachsen (Alfred, King of the Anglo-Saxons). In this aria, the soprano soloist's expressive vocal line is accompanied exclusively by a sextet of clarinets, bassoons, and horns. H. C. Robbins Landon suggests that the Arie des Schutzgeistes is "certainly the most beautiful and original piece in the Alfred music," noting that "[i]f anything were needed to show that the Interlude from The Seven Words is not an isolated phenomenon, and that Haydn was becoming increasingly interested in the capabilities of wind instruments in general, this Aria is a perfect case in point." ${ }^{143}$ The fact that both compositions followed directly upon Haydn's time in England clearly demonstrates the influence that the wind music of Britain had upon the composer's later works. Haydn seems to have been intent in these two movements on demonstrating the versatility of the wind ensemble in its ability to accompany a dramatic vocal aria (Alfred) as well as to carry an entire movement within an symphonic work (Seven Last Words). For Haydn, wind writing had obviously become more than a simple matter of orchestral

\footnotetext{
${ }^{143}$ Landon, Haydn Chronicle IV, 184.
} 
color. The aria and Overture signal the composer's new-found admiration for the winds as instruments fully capable of artistic sophistication.

Haydn's late predilection for wind writing is even more evident in the series of Masses that form the core of his post-London repertoire. Though Haydn was to write no more symphonies after No. 104 - popularly subtitled the "London" Symphony to emphasize its status as the culmination of the final set of twelve - the formal and dramatic elements of his symphonies informed the structural composition of his late Masses, which employ a full orchestral complement. Scholars have detected a symphonic structure in the ordering of fast, slow, and dance-like sections in several of the Masses, suggesting that these works may in fact represent the composer's continuation of the symphony on a grander scale, both in terms of performing forces and dramatic content. Haydn incorporates a more or less full woodwind and brass force in each of his late vocal works. The tonal palette of the winds is displayed in these pieces, with the wind instruments serving as important voices not merely subservient to the string choir.

The most notable use of the wind ensemble in the late Haydn Masses comes not in the Harmoniemesse but in what is perhaps the most dramatic of the late works, the Mass In tempore belli (Mass in Time of War). The wind section in this work is almost as large of that in the Harmoniemesse, featuring paired oboes, clarinets, bassoons, and horns, with the horn players doubling on trumpets. In the closing Agnus Dei movement, Haydn essentially revisits the pictorialism of the "Military Symphony," with the wind section once again serving as the evocation of an advancing military band. With Napoleon's army quite literally approaching the city gates of Vienna at the time, the allusion was even more visceral to the listeners of this Mass than it had been to the British audiences who had been thrilled by the "Military" Symphony. 
Once again, the use of percussion serves as a signifier of the army, though Haydn forgoes the inclusion of the "Turkish" battery in this case, relying upon the timpani to relay the sounds of war drums. ${ }^{144}$ As the chorus intones the Agnus Dei, with its plea for peace, the timpani and winds provide the impression, in Griesinger's words, that "one [can] hear the enemy already coming in the distance." ${ }^{\prime 45}$ The sonic threat of war increases the dramatic force of the call for peace, creating an aesthetic tension that must have left its original audience shaken to the core. H.C. Robbins Landon sums up the Sublime emotional effect that the Agnus Dei must have had upon its contemporary audience by suggesting that listeners would have been affected "in a way that possibly no religious music had done since the days of Bach and Handel." ${ }^{\text {"46 }}$ The imagined scene - an anxious populace huddled in prayer behind the city walls as a vast army approaches could have provided the perfect fodder for an epic war painting by Wolfe or Loutherbourg.

The musical trickery that Haydn uses to evoke images of Napoleon's encroaching forces in the Messe in tempore belli was clearly gleaned from his experience with the British military aesthetic. The use of distinctive rhythms to evoke the enemy calls to mind the similar use of rhythm in both the Allegretto and the third movement Trio of the "Military" Symphony; Landon refers to this rhythmic effect as an "anapestic rhythm ... which creeps into Haydn's sinister drum-beats of "uncanny nervousness." Landon suggests that "even more terrifying are the trumpet calls (supported by the other wind instruments) which rage through the orchestra."147 Like the trumpet fanfare in the "Military" Symphony's Allegretto coda, these calls serve to herald sublime terror. Not coincidentally, the Mass's trumpet fanfares also feature the distinctive triplet rhythms that had distinguished Haydn's two marches for Henry Harpur's Derbyshire

\footnotetext{
${ }^{144}$ The prominence of the timpani inspired a second nickname for the work: Paukenmesse.

145 Griesinger, "Biographical Notes," 62.

${ }^{146}$ Landon, Haydn Chronicle IV, 175.

${ }^{147}$ Ibid.
} 
cavalry regiment and its accomplished bugler. If the overt references to the aesthetic of the "Military" Symphony are not enough to suggest the influence of Haydn's experience of British military patriotism upon his Mass "in time of war," the fact that this Mass was penned, like the Overture to the Seven Last Words and the Arie from Alfred, in 1796, the very time at which the refinement of the wind ensemble was foremost upon the composer's mind.

Strikingly, the last major large-scale work of Haydn's career was a Mass whose wind writing was notable that the work was popularly dubbed the Harmoniemesse. Completed in 1802, the Mass was written in the same year as the Hungarian National March, demonstrating Haydn's continued interest in wind writing up to the time that he became physically unable to compose. The Harmoniemesse's wind section of flute and paired oboes, clarinets, bassoons, horns, and trumpets (in addition to timpani, strings, and organ), while not large by later orchestral standards, was thought quite considerable at the time. ${ }^{148}$ The integration of this wind section in a choral symphonic setting represented Haydn's compositional sophistication at its peak. Though Haydn may have, in his words, "only just learned in my old age how to use wind instruments," the legacy of his late choral works demonstrates the importance of the winds to the composer's musical language.

${ }^{148}$ Landon, Haydn Chronicle V, 243. 


\section{Conclusion}

By the time of Haydn's death in 1809, the instrumentation of the symphony orchestra had been more or less standardized. The Harmonie core of flute, oboes, clarinets, bassoons, and horns, bolstered with trumpet and trombone as in Haydn's late Viennese works, has subsequently constituted the basic symphonic wind section for two centuries. The only major addition to this core wind group is the tuba, whose invention finally ended a long search for a sufficiently strong bass voice within the wind ensemble, ultimately surpassing the courtal, serpent, ophecleide, and various other short-lived inventions. All other orchestral winds, such as piccolo, English horn, bass clarinet, and contrabassoon, are essentially variants of Harmonie instruments. In the modern wind ensemble, a similar instrumentation remains at the center, with one notable addition: the saxophone, an instrument that rarely appears on symphony concerts but has become customary within the wind band.

The standard format of the symphony was also more or less established by 1809 , in no small part due to Haydn's efforts. The twelve "London" symphonies, in particular, served as models for a new generation of Romantic-era symphonists led by Haydn's composition student, Ludwig van Beethoven. Many of the formal, orchestrational, and dramatic elements that distinguish Haydn's late symphonies are borrowed and expanded upon by Beethoven in his own nine symphonies. Where the elderly Haydn had felt that he had "only just learned . . how to use wind instruments," the young Beethoven was able to build upon his teacher's knowledge in furthering the possibilities of symphonic wind writing. In his famed fifth symphony, for example, Beethoven incorporates an unprecedented solo oboe cadenza in the first movement and adds piccolo and contrabassoon to the instrumentation at the beginning of the fourth movement, effectively adding two octaves to his orchestra's range. These wind moments are more than 
mere color effects; they shape the dramatic and expressive scope of the work. Throughout the nineteenth century, symphony composers would continue to expand the tonal and expressive range of the orchestral winds, aided by technical innovations such as valves and extended key systems that would enhance the virtuosity of the woodwind and brass instruments.

The dramatic elements of Haydn's late works, which had evoked terrifyingly sublime imagery in the imaginations of his listeners, were perfectly suited to composers of the burgeoning Romantic era. Some composers built upon the model of the "Military" Symphony in crafting sublime musical depictions, a trend continuing from Haydn's battle call through Berlioz's guillotine and witches' Sabbath to Shostakovich's evocation of the Nazi army surrounding Leningrad - itself a revisiting of Haydn's tempore belli imagery. In many of these instances of musical Sublimity, wind instruments feature prominently; Berlioz's witches are thematically represented by a weirdly trilling E-flat clarinet, distorting an idée fixe theme that has been presented by a solo clarinet throughout the symphony, while Shostakovich's encroaching army is introduced by the piccolo.

Romantic composers also expanded the dramatic possibilities of symphonic form without recourse to such distinctive imagery. The dissonant chord that opens the finale of Beethoven's ninth symphony, for instance, might be heard as a harmonic improvement upon the "climax of horrid sublimity” from Haydn’s “Military” Symphony. The legacy of Haydn’s war chord continues throughout the Romantic period and beyond, as orchestral moments of the Sublime more often than not feature blaring brass and woodwind sounds inevitably accompanied by timpani rolls mirroring the "thundering of the onset" of battle in the "Military" Symphony. Though Beethoven is often considered the progenitor of musical Romanticism, the influence of his teacher cannot be denied. Works like the "Military" Symphony and the Messe in tempore 
belli clearly set the stage for the great Romantic orchestral masterworks, though their contributions to the Romantic sound have routinely been ignored by those who would relegate all of Haydn's music strictly to the category of "Classicism."

The growth and artistic development of the symphony orchestra was to some extent mirrored in the evolution of the wind ensemble, though the role of the wind band would remain unchanged for some time. At the end of Haydn's life, wind ensembles were still largely tied to military organizations, though public performances of marches, orchestral transcriptions, and original wind compositions had begun to gain favor. As the nineteenth and twentieth centuries progressed, advances in wind ensemble growth followed closely upon military conflicts. In Europe, the Harmonie band would maintain its popularity even after the patriotism attending the Napoleonic wars receded with the emperor's banishment. Berlioz's massive Symphonie funebre et triomphale, for expanded Harmonie ensemble, stands as a testament to the dramatic capabilities of the large wind band, even in its early stages. Several Romantic-era composers tried their hand at wind band composition, including Beethoven, Mendelssohn, Wagner, and Dvořák. Transcriptions of popular symphonic operatic music would continue to serve as a staple of wind ensembles in public venues throughout nineteenth-century Europe, as they had been at Esterháza.

A similar wind band growth can be observed in American musical history. The hautboys and Harmonie bands of the American Revolution set the tone for wind music in the United States. A virtual wind band explosion followed the Civil War, as military musicians returned home and formed civic ensembles across the nation. The post-war bands of Patrick Gilmore and John Philip Sousa established the public wind band as a vital facet of American musical culture. Charles Ives, often cited by scholars as the first distinctly "American" orchestral composer, was 
the son of a Civil War bandmaster. Ives's music would continually reference the popular band tunes of his father's era.

After World War I, the modern wind band flourished as military musicians established public bands both in America and across Europe. Many of the major composers of the twentieth century, including Ralph Vaughan Williams, Gustav Holst, Igor Stravinsky, Arnold Schoenberg, Paul Hindemith, and Darius Milhaud, penned compositions expressly for wind ensemble. These works are far more complex in scope and more difficult to perform than the marches from Haydn's London period, yet, like their eighteenth-century predecessors, they demonstrate a wide array of wind performance circumstances. Haydn provided wind marches for a number of circumstances, including courtly entertainment (the divertimenti and Feldpartitas), the opera (Armide), semi-public wind ensembles (March for the Prince of Wales), and civic bands (Marches for the Derbyshire Cavalry). Similarly, later composers have accepted commissions from the military (Holst's two Suites), symphonic wind sections (Stravinsky's Symphonies of Wind Instruments), school ensembles (Milhaud's Suite Française and Schoenberg's Theme and Variations, op. 43A), and even circus bands (Stravinsky's Circus Polka, written to accompany an elephant act).

For both the symphony orchestra and the wind ensemble, the eighteenth and early nineteenth centuries were a time of great development. As the principal compositional figure of the time, Joseph Haydn played an important role in shaping the future of symphonic music, particularly in the sophisticated use of wind instruments within the standard orchestral genres. At the time of his youthful appointment to the court of Count Morzin, the symphony orchestra was an extension of the opera and the standard wind ensemble was a sextet. By the time of Haydn's death, the symphony orchestra was a venerated artistic institution and the wind 
ensemble was deemed capable of carrying entire movements in choral and orchestral works. The course of Haydn's career runs alongside the development of musical institutions that have shaped Western art music for two centuries. The study of Haydn's wind writing highlights these historic moments of change in a way that sheds new light on both the composer and the growth of instrumental music since his day. 
Bibliography

Bonds, Mark Evan. “The Symphony as Pindaric Ode.” In Haydn and His World, ed. Elaine Sisman, 131-153. Princeton, NJ: Princeton University Press, 1997.

Brown, A. Peter. "The Sublime, the Beautiful, and the Ornamental: English Aesthetic Currents and Haydn's London Symphonies." In Studies in Music History Presented to H.C. Robbins Landon, ed. Otto Biba and David Wyn Jones, 44-70. London: Thames and Hudson Ltd., 1996.

. The Symphonic Repertoire, Vol. II: The First Golden Age of the Viennese Symphony: Haydn, Mozart, Beethoven, and Schubert. Bloomington: Indiana University Press, 2002.

Dies, Albert Christoph. "Biographical Accounts of Joseph Haydn, According to His Spoken Narration.” In Joseph Haydn:Eighteenth-Century Gentleman and Genius, ed. Vernon Gotwals, 67-209. Madison, WI: University of Wisconsin Press, 1963.

Farmer, Henry George. Handel's Kettledrums, and Other Papers on Military Music. London: Hinrichsen Edition, Ltd., 1965. . Military Music. World of Music series, no. 12. London: Parrish, 1950.

. The Rise and Development of Military Music. London: William Reeves, 1912.

Fennell, Frederick. Time and the Winds. Kenosha, WI: Leblanc Publications, 1954.

Goldman, Richard Franko. The Concert Band. New York: Rinehart and Co., 1946.

Gotwals, Vernon, ed. Joseph Haydn: Eighteenth-Century Gentleman and Genius. Madison, WI: University of Wisconsin Press, 1963.

Griesinger, Georg August. "Biographical Notes Concerning Joseph Haydn." In Joseph Haydn: Eighteenth-Century Gentleman and Genius, ed. Vernon Gotwals, 1-66. Madison, WI: University of Wisconsin Press, 1963.

Haas, Karl. “Haydn’s English Military Marches.” The Score 2 (1950).

Haydn, Franz Joseph. Armida: Dramma Eroico. Joseph Haydn Werke, series XXV, vol. 2. Joseph Haydn-Institut, Köln. Munich-Duisburg: G. Henle Verlag, 1965.

. Londener Sinfonien 3. Joseph Haydn Werke, series I, vol. 17. Joseph Haydn-Institut, Köln. Munich-Duisburg: G. Henle Verlag, 1966.

. Die Siebenletzten Worte unseres Erlösers am Kreuze Vokalfassung. Joseph Haydn Werke, series XXVIII, vol. 2. Joseph Haydn-Institut, Köln. Munich-Duisburg: G. Henle Verlag, 1961. 
Haydn, Franz Joseph. Tänze und Märsche. Joseph Haydn Werke, series V. Joseph HaydnInstitut, Köln. Munich-Duisburg: G. Henle Verlag, 1995.

Head, Matthew. 'Haydn's Exoticisms: 'Difference' and the Enlightenment.” In The Cambridge Companion to Haydn, ed. Caryl Clark, 61-76. Cambridge: Cambridge University Press, 2005.

Hellyer, Roger. “The Wind Ensemble of the Esterházy Princes, 1761-1813.” Haydn Yearbook 15 (1984): 5-92.

Hogwood, Christopher. Haydn's Visits to England. London: The Folio Society, 1980.

Landon, H.C. Robbins. The Collected Correspondence and London Notebooks of Joseph Haydn. Fair Lawn, NJ: Essential Books, 1959.

Landon, H. C. Robbins. Haydn: Chronicle and Works, Vol. I: Haydn: The Early Years 17321765. Bloomington, IN: Indiana University Press, 1980.

. Haydn: Chronicle and Works, Vol. II: Haydn at Esterháza 1766-1790. Bloomington, IN: Indiana University Press, 1978.

. Haydn: Chronicle and Works, Vol. III: Haydn in England 1791-1795. Bloomington, IN: Indiana University Press, 1976.

. Haydn: Chronicle and Works, Vol. IV: The Years of 'The Creation' 1796-1800.

Bloomington, IN: Indiana University Press, 1977.

. Haydn: Chronicle and Works, Vol V: Haydn: the Late Years 1801-1809.

Bloomington, IN: Indiana University Press, 1977.

. The Symphonies of Joseph Haydn. London: Universal Editions and Rockliff Publishing Company, 1955.

Langford, Paul. Englishness Identified: Manners and Character 1650-1850. Oxford: Oxford University Press, 2000.

Matthews, Betty. "Haydn's Visit to Hampshire and the Isle of Wight, Described from Contemporary Sources." Haydn Yearbook 3 (1965): 111-21.

McVeigh, Simon. Concert Life in London from Mozart to Haydn. Cambridge: Cambridge University Press, 1993.

Montagna, Dennis. "Benjamin West's The Death of Wolfe: A Nationalist Narrative." American Art Journal 12 (Spring, 1981): 72-88. 
Morrow, Mary Sue. Concert Life in Haydn's Vienna: Aspects of a Developing Musical and Social Institution. Sociology of Music, no. 7. Stuyvesant, NY: Pendragon Press, 1989.

Schroeder, David P. “Audience Reception and Haydn's London Symphonies.” International Review of the Aesthetics and Sociology of Music 16 (1985): 57-72.

Haydn and the Enlightenment: The Late Symphonies and Their Audience. Oxford: Oxford University Press, 1990.

. "Orchestral Music: Symphonies and Concertos." In The Cambridge Companion to Haydn, ed. Caryl Clark, 95-111. Cambridge: Cambridge University Press, 2005.

Somfai, László. “The London Revision of Haydn’s Instrumental Style.” Proceedings of the Royal Musical Association 100 (1973-74): 159-74.

Spitzer, John, and Neal Zaslaw. The Birth of the Orchestra: History of an Institution, 1650-1815. Oxford: Oxford University Press, 2004.

Tolley, Thomas. Painting the Cannon's Roar: Music, the Visual Arts and the Rise of an Attentive Public in the Age of Haydn, c. 1750 to c. 1810. Ashcroft, England: Ashgate Publishing Company, 2001.

Webster, James. "Haydn's Aesthetics." In The Cambridge Companion to Haydn, ed. Caryl Clark, 30-44. Cambridge: Cambridge University Press, 2005.

Whitwell, David. The History and Literature of the Wind Band and Wind Ensemble, Vol. 4: The Wind Band and Wind Ensemble of the Classical Period (1750-1800). Northridge, CA: WINDS, 1982-1991. . A New History of Wind Music. Northfield, IL: The Instrumentalist Co., 1972.

Wright, Al G., and Stanley Newcomb. Bands of the World. Evanston, IL: The Instrumentalist Co., 1970.

Wyn Jones, David. Haydn. Oxford Composer Companions, ed. Otto Biba. Oxford: Oxford University Press, 2002.

."Haydn's Music in London in the Period 1760-1790: Part One." Haydn Yearbook 14 (1984): 144-72. 